\title{
Nitrogen and carbon flows between the caecum, blood and rumen in sheep given chopped lucerne (Medicago sativa) hay
}

\author{
BY R. M. DIXON* AND J. V. NOLAN \\ Department of Biochemistry and Nutrition, Faculty of Rural Science, \\ University of New England, Armidale, NSW 2351, Australia
}

\section{(Received 9 September 1985 - Accepted 13 September 1985)}

\begin{abstract}
1. Experiments involving ${ }^{15} \mathrm{~N}$ and ${ }^{14} \mathrm{C}$ tracers were made in sheep consuming $800 \mathrm{~g}$ air-dry chopped lucerne (Medicago sativa) hay/d and providing $20.4 \mathrm{~g} \mathrm{~N} / \mathrm{d}$ to study $\mathrm{N}$ and $\mathrm{C}$ flows within the caecal digesta and between the caecum, blood and rumen.

2. Continuous infusions of ${ }^{15} \mathrm{~N}$ tracers were made into the caecal ammonia, blood urea and rumen $\mathrm{NH}_{3}$ pools. The concentration and enrichment of caecal digesta $\mathrm{NH}_{3}-\mathrm{N}$, caecal microbial $\mathrm{N}$, caecal digesta non-urea, non-ammonia-N (NU-NAN), faecal NU-NAN, blood urea- $\mathrm{N}$, rumen digesta $\mathrm{NH}_{3}-\mathrm{N}$ and rumen bacterial $\mathrm{N}$ were estimated at intervals during the infusions. A three-pool open-compartment model was solved to estimate $\mathrm{N}$ flows between the caecal digesta $\mathrm{NH}_{3}-\mathrm{N}$, blood urea- $\mathrm{N}$ and rumen digesta $\mathrm{NH}_{3}-\mathrm{N}$ pools.

3. The rate of irreversible loss from the caecal digesta $\mathrm{NH}_{3}-\mathrm{N}$ pool was $2 \cdot 17$ (SE 0.623 ) g N/d. On average 0.9 (SE 0.56 ) g N/d of caecal digesta $\mathrm{NH}_{3}-\mathrm{N}$ was derived from blood urea and 0.1 (SE 0.08 ) g caecal digesta $\mathrm{NH}_{3}-\mathrm{N} / \mathrm{d}$ was apparently derived from the fermentation of undigested rumen microbes in the caecum. The amount of $\mathrm{NH}_{3}-\mathrm{N}$ produced by proteolysis and deamination of dietary and endogenous $\mathrm{N}$ was $1 \cdot 1(\mathrm{SE} 0 \cdot 13) \mathrm{g} / \mathrm{d}$.

4. There was net incorporation of $0.56(\mathrm{SE} 0.306) \mathrm{g}$ caecal digesta $\mathrm{NH}_{3}-\mathrm{N} / \mathrm{d}$ into caecal microbes. The microbial $\mathrm{V}$ synthesized de novo in the caecum was not determined, but 2.9 (SE 0.52 ) g microbial N/d of both rumen and vaecal origin flowed out of the caecum and constituted 0.48 of the NU.NAN flow. The majority (mean 0.83 (SE 1).044)) of this microbial $\mathrm{N}$ was excreted in faeces.

5. On average $1.8(\mathrm{SE} 0.80) \mathrm{g}$ caecal digesta $\mathrm{NH}_{3}-\mathrm{N} / \mathrm{d}$ were absorbed. Of this $\mathrm{NH}_{3}-\mathrm{N}, 0.92$ (SE 0.054$)$ was converted to blood urea, contributing 0.10 (SE 0.031 ) of blood urea-N. Only 0.012 (SE 0.0041 ) of rumen digesta $\mathrm{NH}_{3}-\mathrm{N}$ and $0 \cdot 005$ (SE 0.0009 ) of rumen bacterial $\mathrm{N}$ were derived from caecal digesta $\mathrm{NH}_{3}-\mathrm{N}$.

6. Infusions of ${ }^{14} \mathrm{C}$ tracers were made into the caecal digesta bicarbonate, blood bicarbonate, rumen digesta bicarbonate and blood urea pools, and samples were obtained at intervals to determine the specific radioactivity of each pool. A four-pool open-compartment model was solved to estimate $C$ flows between these pools.

7. The rate of irreversible loss of blood urea estimated with $\left[{ }^{14} \mathrm{C}\right]$ urea $(17 \cdot 1(\mathrm{SE} 1 \cdot 18) \mathrm{g} \mathrm{N} / \mathrm{d})$ was greater $(P<0.01)$ than that estimated with $\left[{ }^{15} \mathrm{~N}\right]$ urea $(14.0($ SE 0.87$) \mathrm{g} \mathrm{N} / \mathrm{d})$.

8. Transfer of blood urea to the caecal digesta estimated with ${ }^{14} \mathrm{C}$ tracers $(1.4(\mathrm{SE} 0.61) \mathrm{g} \mathrm{N} / \mathrm{d})$ was greater $(P<0.01)$ than that estimated with ${ }^{15} \mathrm{~N}$ tracers $(0.9($ SE 0.56$) \mathrm{g} \mathrm{N} / \mathrm{d})$. The estimate of transfer of blood urea to the rumen digesta was also greater with ${ }^{14} \mathrm{C}$ tracers $(P<0.05 ; 1.7$ (SE 0.15$)$ and $1.2(\mathrm{sE} 0.19) \mathrm{g} \mathrm{N} / \mathrm{d}$ respectively). The urea hydrolysed in the gastrointestinal tract other than in the rumen digesta pool and the caecal digesta pool was 0.56 of total urea hydrolysis when estimated with ${ }^{14} \mathrm{C}$ tracers, or 0.69 when estimated with ${ }^{15} \mathrm{~N}$ tracers. Results from previous acute experiments suggested that with three of the four observations made in three sheep in the present experiment the transfer of blood urea to the caecal digesta could have occurred entirely via ileal digesta. Similarly, urea transfer to the rumen digesta could have occurred entirely via saliva.
\end{abstract}

A considerable amount of ammonia is produced in the large intestine of sheep by hydrolysis of endogenous urea and by proteolysis and deamination of dietary and endogenous materials entering from the small intestine. The apparent absorption of $\mathrm{NH}_{3}$ and other nitrogeneous materials between the ileum and the rectum has been measured in numerous studies with sheep prepared with cannulas in the ileum (Coelho da Silva et al. 1972a,b; MacRae \& Ulyatt, 1974; Beever et al. 1976) and also by sampling various parts of the large intestine during acute experiments (Dixon \& Nolan, 1982). It is generally thought that there is negligible absorption of amino acids, and that apparent digestion of nitrogen is due to absorption of $\mathrm{NH}_{3}$ (Ulyatt et al. 1975; Hoover, 1978). Since hydrolysis of urea occurs only n the gastrointestinal tract by the action of urease $(E C$ 3.5.1.5) of bacterial origin

* Present address: School of Agriculture and Forestry, University of Melbourne, Parkville, Victoria 3052, tustralia. 
(Kornberg \& Davies, 1955), the quantity of endogenous urea hydrolysed in the post-ruminal tract has been estimated as the differences between the urea hydrolysed in the rumen digesta pool and that hydrolysed in the entire gastrointestinal tract (Nolan \& Leng, 1972; Norton et al. 1978; Kennedy, 1980). ${ }^{15} \mathrm{~N}$ tracers have been used to estimate the flows of urea, $\mathrm{NH}_{3}-\mathrm{N}$ and microbial $\mathrm{N}$ in the large intestine in in vivo (Nolan et al. 1976) and in acute experiments (Dixon \& Nolan, 1983; Dixon \& Milligan, 1984), but the former study was based on injection of ${ }^{15} \mathrm{~N}$ tracers into the caecum of only one sheep while the latter studies depended on a single sample of caecal digesta obtained at slaughter.

The experiments now reported were undertaken in order to gain a better understanding of the kinetics of $\mathrm{N}$ utilization and metabolism in the large intestine of sheep and of the importance of these $\mathrm{N}$ flows in relation to the rest of the body. Flows of $\mathrm{N}$ in intact sheep consuming lucerne (Medicago sativa) hay were measured using in vivo infusions of ${ }^{15} \mathrm{~N}$ and ${ }^{14} \mathrm{C}$ tracers into and sampling from the caecum, blood, rumen, urine and faeces. These results were used to solve multi-pool quantitative models describing $\mathrm{N}$ and $\mathrm{C}$ kinetics in the body. The simultaneous infusion and sampling of ${ }^{15} \mathrm{~N}$ and ${ }^{14} \mathrm{C}$ tracers enabled separate estimates of urea hydrolysis in various parts of the gut. ${ }^{51} \mathrm{Cr}$-EDTA was also administered to estimate the flow of digesta through the caecum.

\section{MATERIALS AND METHODS}

Sheep and preparation

Mature Merino wethers (29-35 kg live weight) of similar genetic origin were prepared with a rumen cannula (Hecker, 1969) and with a cannula and an infusion line into the caecum. Polypropylene cannulas $(60 \mathrm{~mm} \times 17 \mathrm{~mm})$ were implanted one-third of the distance from the ileo-caecal junction to the caecal pole, and were exteriorized through the lower right flank (MacRae et al. 1973). An infusion line (Silastic; Dow Corning, Michigan, USA; internal diameter $1.02 \mathrm{~mm}$ ) into the caecum was securely attached to the caecal wall midway between the cannula and the pole of the caecum. A post-operative recovery period of at least 8 weeks was allowed before experiments were undertaken. Jugular catheters were inserted into one or both jugular veins $8-12 \mathrm{~h}$ before tracer infusions were commenced.

The sheep were held indoors in metabolism crates under continuous lighting and were accustomed to the sampling procedures before experiments commenced. Anthelmintics were administered regularly to control intestinal parasites. The chopped-lucerne-hay diet $(800 \mathrm{~g} / \mathrm{d})$ was given for at least $60 \mathrm{~d}$ before an experiment and given in equal hourly portions for at least $7 \mathrm{~d}$ before and also during each experiment. The lucerne hay contained $903 \mathrm{~g}$ dry matter (DM) $/ \mathrm{kg}$ air-dry material, and $920 \mathrm{~g}$ organic matter and $28 \cdot 3 \mathrm{~g} \mathrm{~N} / \mathrm{kg} \mathrm{DM}$. Water was available at all times.

\section{Experiments}

A series of experiments (Table 1) involving continuous infusions of tracers was carried out with three mature sheep over an interval of 12 months, and some measurements were made twice in two sheep. Infusions of ${ }^{15} \mathrm{~N}$ tracers were made into the caecal digesta $\mathrm{NH}_{3}-\mathrm{N}$, blood urea and rumen digesta $\mathrm{NH}_{3}-\mathrm{N}$ pools, with sampling during each infusion to determine the concentration and enrichment of caecal digesta $\mathrm{NH}_{3}$, caecal non-urea, non-ammonia- $\mathrm{N}$ (NU-NAN), caecal microbial $\mathrm{N}$, blood urea-N, rumen digesta $\mathrm{NH}_{3}-\mathrm{N}$, rumen bacterial $\mathrm{N}$, urinary urea-N and faecal NU-NAN. Infusions of ${ }^{14} \mathrm{C}$ tracers were also made into the caecal digesta bicarbonate, blood bicarbonate, rumen digesta bicarbonate and blood urea pools, and samples were obtained during each infusion to determine the specific radioactivity (SR) of each of these pools. Also, during each infusion of ${ }^{15} \mathrm{~N}$ and ${ }^{14} \mathrm{C}$ tracers, the ${ }^{51} \mathrm{Cr}$-labelled complex of EDTA ( ${ }^{51} \mathrm{Cr}$-EDTA) was infused into the caecum and the ${ }^{51} \mathrm{Cr}$ content in caecal digesta was determined to measure the flow rate of caecal digesta. 
Table 1. Details of tracer infusion experiments giving the sheep used for each experiment, the quantity and infusion site for each tracer, the time-period for which each infusion was made and the number of samples obtained to measure tracer plateau

\begin{tabular}{|c|c|c|c|c|c|c|}
\hline $\begin{array}{l}\text { Expt } \\
\text { no. }\end{array}$ & Sheep & Tracer & $\begin{array}{l}\text { Infusion } \\
\text { site }\end{array}$ & $\begin{array}{l}\text { Infusion } \\
\text { rate }\end{array}$ & $\begin{array}{l}\text { Infusion } \\
\text { period } \\
\text { (min) }\end{array}$ & $\begin{array}{l}\text { No. of } \\
\text { samples }\end{array}$ \\
\hline 1 & A & $\begin{array}{l}{\left[{ }^{15} \mathrm{~N}\right] \text { urea }} \\
{\left[{ }^{14} \mathrm{C}\right] \text { urea }} \\
{ }^{51} \mathrm{Cr} \text {-EDTA }\end{array}$ & $\begin{array}{l}\text { Blood } \\
\text { Blood } \\
\text { Caecum }\end{array}$ & $\begin{array}{l}2.7 \mathrm{mg} \text { atoms }{ }^{15} \mathrm{~N} / \mathrm{d} \\
55 \mu \mathrm{Ci} / \mathrm{d} \\
30 \mu \mathrm{Ci} / \mathrm{d}\end{array}$ & $\begin{array}{l}1460 \\
1460 \\
1390\end{array}$ & $\begin{array}{l}6 \\
7 \\
6\end{array}$ \\
\hline 2 & $A, B, C$ & $\begin{array}{l}{\left[{ }^{15} \mathrm{~N}\right] \text { urea }} \\
{\left[{ }^{14} \mathrm{C}\right] \text { urea }} \\
{ }^{51} \mathrm{Cr} \text {-EDTA }\end{array}$ & $\begin{array}{l}\text { Blood } \\
\text { Blood } \\
\text { Caecum }\end{array}$ & $\begin{array}{l}0.9 \mathrm{mg} \text { atoms }{ }^{15} \mathrm{~N} / \mathrm{d} \\
80 \mu \mathrm{Ci} / \mathrm{d} \\
100 \mu \mathrm{Ci} / \mathrm{d}\end{array}$ & $\begin{array}{l}2030 \\
2030 \\
2500\end{array}$ & $\begin{array}{l}6 \\
6 \\
6\end{array}$ \\
\hline 3 & A, B & $\begin{array}{l}\left({ }^{15} \mathrm{NH}_{4}\right)_{2} \mathrm{SO}_{4} \\
{ }^{51} \mathrm{Cr}-\mathrm{EDTA}\end{array}$ & $\begin{array}{l}\text { Caecum } \\
\text { Caecum }\end{array}$ & $\begin{array}{l}1 \cdot 1 \mathrm{mg} \text { atoms }{ }^{15} \mathrm{~N} / \mathrm{d} \\
30 \mu \mathrm{Ci} / \mathrm{d}\end{array}$ & $\begin{array}{l}1500 \\
1450\end{array}$ & $\begin{array}{l}8 \\
8\end{array}$ \\
\hline 4 & A, B, C & $\begin{array}{l}\left({ }^{15} \mathrm{NH}_{4}\right)_{2} \mathrm{SO}_{4} \\
\mathrm{NaH}^{14} \mathrm{CO}_{3} \\
{ }^{51} \mathrm{Cr}-\mathrm{EDTA}\end{array}$ & $\begin{array}{l}\text { Caecum } \\
\text { Caecum } \\
\text { Caecum }\end{array}$ & $\begin{array}{l}3.3 \mathrm{mg} \text { atoms }{ }^{15} \mathrm{~N} / \mathrm{d} \\
510 \mu \mathrm{Ci} / \mathrm{d} \\
100 \mu \mathrm{Ci} / \mathrm{d}\end{array}$ & $\begin{array}{l}2100 \\
2100 \\
2050\end{array}$ & $\begin{array}{l}6 \\
6 \\
6\end{array}$ \\
\hline 5 & A, B, C & $\begin{array}{l}\mathrm{NaH}^{14} \mathrm{CO}_{3} \\
{ }^{51} \mathrm{Cr}-\mathrm{EDTA}\end{array}$ & $\begin{array}{l}\text { Caecum } \\
\text { Caecum }\end{array}$ & $\begin{array}{l}50 \mu \mathrm{Ci} / \mathrm{d} \\
20 \mu \mathrm{Ci} / \mathrm{d}\end{array}$ & $\begin{array}{l}1270 \\
1250\end{array}$ & $\begin{array}{l}8 \\
8\end{array}$ \\
\hline 6 & $\mathrm{~A}, \mathrm{~B}, \mathrm{C}$ & $\begin{array}{l}\mathrm{NaH}^{14} \mathrm{CO}_{3} \\
{ }^{51} \mathrm{Cr}_{\mathrm{r}}-\mathrm{EDTA}\end{array}$ & $\begin{array}{l}\text { Blood } \\
\text { Caecum }\end{array}$ & $\begin{array}{l}42 \mu \mathrm{Ci} / \mathrm{d} \\
15 \mu \mathrm{Ci} / \mathrm{d}\end{array}$ & $\begin{array}{l}1170 \\
1100\end{array}$ & $\begin{array}{l}8 \\
7\end{array}$ \\
\hline 7 & $A, B, C$ & $\begin{array}{l}\left({ }^{15} \mathrm{NH}_{4}\right)_{2} \mathrm{SO}_{4} \\
\mathrm{NaH}^{14} \mathrm{CO}_{3}\end{array}$ & $\begin{array}{l}\text { Rumen } \\
\text { Rumen }\end{array}$ & $\begin{array}{l}3.8 \mathrm{mg} \text { atoms }{ }^{15} \mathrm{~N} / \mathrm{d} \\
580 \mu \mathrm{Ci} / \mathrm{d}\end{array}$ & $\begin{array}{l}2100 \\
2100\end{array}$ & $\begin{array}{l}5 \\
5\end{array}$ \\
\hline
\end{tabular}

A total collection of urine and faeces for $8 \mathrm{~d}$ was also made from the three sheep plus one additional sheep.

\section{Preparation and administration of tracers}

The ${ }^{51} \mathrm{Cr}$-EDTA was obtained from Lucas Heights, Sydney, Australia; ${ }^{14} \mathrm{C}$ tracers from Amersham International, Amersham, Bucks UK; $\left({ }^{15} \mathrm{NH}_{4}\right)_{2} \mathrm{SO}_{4}$ from the British Oxygen Co., London (97 atoms \%) or from Adlershof, Berlin (96.2 atoms \%); and $\left[{ }^{15} \mathrm{~N}\right]$ urea (96 atoms $\%$ ) from ONIA, Paris. The ${ }^{51} \mathrm{Cr}$-EDTA was mixed with carrier Cr-EDTA (Binnerts et al. $1968 ; 1-7 \mathrm{mg} \mathrm{Cr} / \mu \mathrm{Ci}$ ). The $\mathrm{NaH}{ }^{14} \mathrm{CO}_{3}$ was washed from the ampoule in which it was supplied using a solution containing $\mathrm{NaHCO}_{3}$ as carrier. $\left[{ }^{14} \mathrm{C}\right]$ urea was mixed with $\left[{ }^{15} \mathrm{~N}\right]$ urea and therefore no additional carrier urea was used.

The intravenous infusions were administered at $0.08-0.12$ litres $/ \mathrm{d}$ in sterile saline $(0.15$ M-sodium chloride) via a jugular catheter. Infusions into the caecum and into the rumen were in aqueous solution at $0.72-0.78$ litres/d. Water or saline solution was infused for 200-700 min before tracer infusion was begun.

\section{Sampling}

Experiments were at least $10 \mathrm{~d}$ apart, and samples were taken from all sampling sites for analysis for background radioactivity before tracers were administered.

Caecal digesta were sampled after scraping out and discarding digesta in the barrel of the cannula, and then by collecting 30-50 g digesta into a container attached to the cannula. Sometimes digesta were obtained immediately, but often it was necessary to leave the container in position for $1545 \mathrm{~min}$. The digesta were subsampled to enable analysis for ${ }^{51} \mathrm{Cr}$-EDTA (1-4 $\mathrm{g}$ into a tared $\gamma$-counting vial using a glass tube, $7 \mathrm{~mm}$ internal diameter), $\mathrm{DM}(10 \mathrm{~g})$, total $\mathrm{N}$ ( $5 \mathrm{~g}$ into $5 \mathrm{ml} 0.5 \mathrm{M}$-sulphuric acid), and the $\mathrm{SR}$ of $\mathrm{H}^{14} \mathrm{CO}_{3}{ }^{-}(3 \mathrm{~g}$ into 
a McCartney bottle). Another subsample ( $10 \mathrm{~g}$ ) was mixed with $0.5 \mathrm{M}-\mathrm{H}_{2} \mathrm{SO}_{4}(10 \mathrm{ml})$ and centrifuged $(1000 \mathrm{~g}, 1 \mathrm{~min})$ to remove large particulate matter which was discarded; the resulting supernatant fraction was recentrifuged $(16000 \mathrm{~g}, 20 \mathrm{~min})$ to isolate a microbe-rich fraction and the supernatant fraction was also retained for later analysis. The microbe-rich fraction was also washed (Nolan \& Leng, 1972).

Blood $(5-30 \mathrm{ml})$ from the jugular vein was placed into heparinized tubes which were immediately centrifuged $(3000 \mathrm{~g}, 15 \mathrm{~min})$ to separate plasma. Also, during ${ }^{14} \mathrm{C}$ infusions, $5 \mathrm{ml}$ blood were immediately transferred to a McCartney bottle for $\mathrm{H}^{14} \mathrm{CO}_{3}{ }^{-}$analysis.

Rumen fluid samples $(10-20 \mathrm{ml})$ were withdrawn through a nylon-gauze-covered cage in the ventral sac of the rumen. Subsamples $(5 \mathrm{ml})$ were placed into a McCartney bottle for $\mathrm{H}^{14} \mathrm{CO}_{3}^{-}$analysis and, where appropriate, a subsample $(10 \mathrm{ml})$ was acidified $(0.2 \mathrm{ml}$ $\left.5 \mathrm{M}-\mathrm{H}_{2} \mathrm{SO}_{4}\right)$, centrifuged $(16000 \mathrm{~g}, 20 \mathrm{~min})$ and the supernatant fraction retained. Bacteriarich samples were also isolated from the pellet obtained by this centrifugation and washed (Nolan \& Leng, 1972).

Urine was collected into glacial acetic acid $(20 \mathrm{ml} / \mathrm{d})$ containing $1 \mathrm{~g}$ mercuric chloride $/ \mathrm{l}$. During ${ }^{15} \mathrm{~N}$ infusions, faeces and urine were obtained during the last $240 \mathrm{~min}$ of the infusion and $10-\mathrm{g}$ samples of faeces were acidified with $5 \mathrm{ml} 0.5 \mathrm{M}-\mathrm{H}_{2} \mathrm{SO}_{4}$.

All samples awaiting analysis were stored at $-20^{\circ}$.

\section{Laboratory procedures}

$\mathrm{DM}$, organic matter and total $\mathrm{N}$ content of food and digesta were determined by standard procedures (Association of Official Analytical Chemists, 1975). The concentration and enrichment of $\mathrm{NH}_{3}-\mathrm{N}$, total $\mathrm{N}, \mathrm{NU}-\mathrm{NAN}$ and microbial $\mathrm{N}$ in digesta, and urea- $\mathrm{N}$ in plasma and urine were determined by the procedures described by Dixon \& Nolan (1983). The radioactivity of ${ }^{51} \mathrm{Cr}$-EDTA in digesta and faeces was determined as described by Dixon et al. (1982).

The SR of urea in plasma and urine were determined as described by Nolan \& Leng (1970) and the SR of $\mathrm{H}^{14} \mathrm{CO}_{3}^{-}$by the procedures of Leng \& Leonard (1965) following isolation of the acid-labile $\mathrm{HCO}_{3}{ }^{-}$as $\mathrm{Ba}^{14} \mathrm{CO}_{3} . \mathrm{NaH}^{14} \mathrm{CO}_{3}$ infusate was sampled several times during each infusion, an appropriate volume added to a known weight of sodium carbonate and diluted with bicarbonate-free water, and $\mathrm{Ba}^{14} \mathrm{CO}_{3}$ analysed as for the samples. $\left[{ }^{14} \mathrm{C}\right]$ toluene of known SR (Lucas Heights, Australia) was used to construct efficiency-correction curves for the toluene-triton $\mathrm{X}$ scintillation cocktail. The radioactivity of $\mathrm{NaH}^{14} \mathrm{CO}_{3}$ infusate was determined by direct counting, and $\mathrm{Ba}^{14} \mathrm{CO}_{3}$ standards prepared from this infusate were used to construct an efficiency-correction curve for the scintillation mixture containing thixotropic gel powder (Cab-o-sil, Packard Instrument Co., USA) used to count the $\mathrm{Ba}^{14} \mathrm{CO}_{3}$ samples. The differences in SR between groups of $\mathrm{Ba}^{14} \mathrm{CO}_{3}$ standards prepared independently were less than $3 \%$. The coefficient of variation of the SR of $\left[{ }^{14} \mathrm{C}\right]$ urea standards was less than $1 \%$, and of $\mathrm{Ba}^{14} \mathrm{CO}_{3}$ standards $1-4 \%$. The SR of blood urea-C determined on protein-precipitated supernatant solutions was found to be $0.30-0.60$ greater than the concurrent SR of urinary urea-C during the plateau of $\mathrm{H}^{14} \mathrm{CO}_{3}{ }^{-}$infusions, presumably because there were ${ }^{14} \mathrm{C}$-labelled compounds other than urea in the deproteinized plasma. There were no detectable differences between the SR of bood urea- $\mathrm{C}$ and urinary urea- $\mathrm{C}$ during infusion of $\left[{ }^{14} \mathrm{C}\right]$ urea into the blood, thereby confirming the validity of the deproteinization procedures of Cocimano \& Leng (1967) for determination of the SR of blood urea in $\left[{ }^{14} \mathrm{C}\right]$ urea infusion experiments. Consequently the SR of blood urea-C during infusions of $\mathrm{H}^{14} \mathrm{CO}_{3}$ was estimated from the SR of urinary urea-C collected during the last 240 min of $\mathrm{H}^{14} \mathrm{CO}_{3}$ infusion. 


\section{Calculations}

Results were normalized to infusion rates $(/ \mathrm{d})$ of $1.44 \times 10^{6}$ counts $/ \mathrm{min}$ for ${ }^{51} \mathrm{Cr}$-EDTA, $100 \mu \mathrm{Ci}$ for $\left[{ }^{14} \mathrm{C}\right]$ urea and $\mathrm{H}^{14} \mathrm{CO}_{3}{ }^{-}$, and $5 \mathrm{mg}$ atoms for $\left({ }^{15} \mathrm{NH}_{4}\right)_{2} \mathrm{SO}_{4}$ and $\left[{ }^{15} \mathrm{~N}\right]$ urea.

The time-point at which plateau ${ }^{15} \mathrm{~N}$ and ${ }^{14} \mathrm{C}$ tracer concentration was considered to have been reached was determined visually by examining the tracer concentration with time-curves for all sheep in similar experiments. The flow rate of digesta components through the caecum was calculated from the six to ten observations of ${ }^{51} \mathrm{Cr}$-EDTA concentration in caecal digesta sampled more than $250 \mathrm{~min}$ after the commencement of the infusion (Dixon et al. 1982). The rate of irreversible loss of traced substance from a primary pool, the proportion of traced substance in a secondary pool derived from a primary pool and the proportion of $\left({ }^{15} \mathrm{NH}_{4}\right)_{2} \mathrm{SO}_{4}$ infused into the caecum incorporated into blood urea were calculated by the procedures described by Shipley \& Clark (1972), Nolan \& Leng (1974) and Dixon \& Nolan (1983). The blood urea transfer to the gastrointestinal tract other than the rumen and the caecum was calculated as the rate of irreversible loss estimated with $\left[{ }^{14} \mathrm{C}\right]$ urea minus urea transfer to the rumen digesta and the caecal digesta minus urinary urea excretion.

\section{Model construction}

Three-pool and four-pool open-compartment models were used to describe the flows of $\mathrm{N}$ and $\mathrm{C}$ respectively between the caecum, rumen and blood.

The methods of Mann \& Gurpide (1966) and Nolan et al. (1976) were used to solve equations representing the rates of flow of $\mathrm{N}$ or $\mathrm{C}$ in these models. Tracers were infused into each pool in each sheep in independent experiments so that separate models could be constructed from sets of data from each sheep. Data set 1 was developed for sheep A from Expts 1, 3, 5, 6 and 7. Data sets 2, 3 and 4 were developed for sheep A, B and C respectively from Expts 2, 4, 6 and 7. Values derived for data sets 1 and 2 were used to calculate the mean values for sheep A. The standard errors of the individual flows were calculated from the model solutions for the three sheep.

\section{Statistical analysis}

Differences between the mean values for flows of digesta or the concentrations of $\mathrm{NH}_{3}-\mathrm{N}$ or urea- $\mathrm{N}$ for the various sheep on different experimental days were examined by one-way analysis of variance. Differences between means were compared using the $5 \%$ StudentNewman-Keuls test. A paired $t$ test was used to compare rates of irreversible loss and transfers of urea measured using ${ }^{15} \mathrm{~N}$ and ${ }^{14} \mathrm{C}$ tracers for the four data sets. The slopes and elevations of regression lines were compared using the methods of Snedecor \& Cochran (1967).

\section{RESULTS}

Variation in concentration and flow of $N$ in the sampled pools

There were significant differences $(P<0.05, P<0.01)$ in the caecal water flow and in the concentrations of caecal digesta $\mathrm{NH}_{3}-\mathrm{N}$, rumen digesta $\mathrm{NH}_{3}-\mathrm{N}$ and blood urea-N among sheep and among tracer infusions within any one sheep (Table 2). However the differences between Expts 3 and 4 for sheep A and B, or between Expts 1 and 2 for sheep A, were associated with measurements 12 months apart, and differences were in almost all cases non-significant within any one sheep measured at intervals over several weeks (e.g. sheep $\mathrm{A}, \mathrm{B}$ or $\mathrm{C}$ in Expts 2, 4 and 7). Within periods of infusion of ${ }^{15} \mathrm{~N}$ tracers there were only small changes in concentrations of caecal digesta $\mathrm{NH}_{3}-\mathrm{N}$, rumen digesta $\mathrm{NH}_{3}-\mathrm{N}$ and blood urea-N, the variations shown in Fig. 1(a) being typical. The coefficient of variation in concentration of caecal digesta $\mathrm{NH}_{3}-\mathrm{N}$ was somewhat greater than that of rumen digesta $\mathrm{NH}_{3}-\mathrm{N}$ or blood urea. 
Table 2. Flow of water through the caecal digesta pool measured by continuous infusion of ${ }^{51} \mathrm{Cr}-E D T A$, concentrations of ammonia-nitrogen in caecal and rumen digesta and concentration of blood urea-N measured during continuous infusions of $\left({ }^{15} \mathrm{NH}_{4}\right)_{2} \mathrm{SO}_{4}$ into the caecum or rumen, or $\left[{ }^{14} \mathrm{C}\right]$ - and $\left[{ }^{15} \mathrm{~N}\right]$ urea into the blood

(Mean values for each infusion and the number of observations are given)

\begin{tabular}{|c|c|c|c|c|c|c|c|c|c|}
\hline \multirow{2}{*}{$\begin{array}{l}\text { Infusion } \\
\text { site and } \\
\text { Expt no. }\end{array}$} & \multirow[b]{2}{*}{ Sheep } & \multicolumn{2}{|c|}{$\begin{array}{c}\text { Caecal water } \\
\text { flow }(1 / d)\end{array}$} & \multicolumn{2}{|c|}{$\begin{array}{c}\text { Caecal } \mathrm{NH}_{3} \\
\text { concentration } \\
(\mathrm{mg} \mathrm{N} / \mathrm{l})\end{array}$} & \multicolumn{2}{|c|}{$\begin{array}{l}\text { Blood urea } \\
\text { concentration } \\
(\mathrm{mg} \mathrm{N} / \mathrm{l})\end{array}$} & \multicolumn{2}{|c|}{$\begin{array}{c}\text { Rumen } \mathrm{NH}_{3} \\
\text { concentration } \\
(\mathrm{mg} \mathrm{N} / \mathrm{l})\end{array}$} \\
\hline & & Mean & $n$ & Mean & $n$ & Mean & $n$ & Mean & $n$ \\
\hline \multicolumn{10}{|l|}{ Caecum } \\
\hline 3 & A & $3 \cdot 15$ & 9 & 313 & 11 & - & $\ldots$ & 108 & 10 \\
\hline 4 & A & 3.94 & 6 & 233 & 8 & 237 & 7 & 190 & 8 \\
\hline 3 & B & 2.64 & 7 & 295 & 8 & - & - & - & 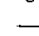 \\
\hline 4 & B & 1.82 & 5 & 219 & 8 & 272 & 8 & 198 & 8 \\
\hline 4 & $\mathrm{C}$ & $2 \cdot 88$ & 5 & 131 & 8 & 244 & 8 & 185 & 8 \\
\hline \multicolumn{10}{|l|}{ Blood } \\
\hline 1 & A & $4 \cdot 17$ & 6 & 293 & 15 & 257 & 15 & 189 & 16 \\
\hline 2 & A & $3 \cdot 74$ & 6 & 226 & 8 & 230 & 7 & 201 & 7 \\
\hline 2 & B & $2 \cdot 39$ & 10 & 212 & 12 & 276 & 10 & 193 & 11 \\
\hline 2 & $\mathrm{C}$ & $3 \cdot 13$ & 6 & 163 & 8 & 242 & 8 & 203 & 8 \\
\hline \multicolumn{10}{|l|}{ Rumen } \\
\hline 7 & A & - & - & 272 & 8 & 206 & 7 & 171 & 7 \\
\hline 7 & B & - & - & 248 & 7 & 233 & 7 & 208 & 7 \\
\hline 7 & $\mathrm{C}$ & - & - & 192 & 8 & 211 & 7 & 161 & 6 \\
\hline SEM & & 0.496 & & 16 & & 6 & & 7 & \\
\hline $\begin{array}{l}\text { Statistical } \\
\text { signi- } \\
\text { ficance: } P<\end{array}$ & & 0.05 & & 0.01 & & 0.01 & & 0.01 & \\
\hline
\end{tabular}

SEM, standard error of the difference between two means.

Infusions of $\left({ }^{15} \mathrm{NH}_{4}\right)_{2} \mathrm{SO}_{4}$ into the caecum

The build-up of ${ }^{15} \mathrm{~N}$ tracer concentrations with time in primary and secondary pools in one sheep are shown in Fig. 1(c); the results for other sheep were similar.

The rate of irreversible loss of $\mathrm{NH}_{3}-\mathrm{N}$ from the caecal digesta pool was 2.17 (SE 0.623 ) $\mathrm{g} \mathrm{N} / \mathrm{d}$ (Table 3). There were differences among sheep from 1.5 to $3.4 \mathrm{~g} \mathrm{~N} / \mathrm{d}$; estimates made 12 months apart were similar in sheep $B$ but differed by $1.3 \mathrm{~g} \mathrm{~N} / \mathrm{d}$ in sheep A. On average 0.92 (SE 0.054 ) of the caecal digesta $\mathrm{NH}_{3}-\mathrm{N}$ that was absorbed from the large intestine apparently entered the blood urea pool and contributed $0 \cdot 10$ (SE 0.031) of this pool. The proportion of the rumén digesta $\mathrm{NH}_{3}-\mathrm{N}$ pool derived from the caecal digesta $\mathrm{NH}_{3}-\mathrm{N}$ was 0.012 (SE 0.0041) and the proportion of rumen bacterial N 0.005 (SE 0.0009).

The loss of $\mathrm{NH}_{3}-\mathrm{N}$ from the caecal digesta pool in water flowing to the colon was $0 \cdot 70$ (SE $0 \cdot 150$ ) $\mathrm{g} \mathrm{N} / \mathrm{d}$, while $0.56(\mathrm{SE} 0.306) \mathrm{g} \mathrm{N} / \mathrm{d}$ was lost by net synthesis into microbial $\mathrm{N}$. Microbial N constituted 0.48 of the NU-NAN flowing from the caecum, and 0.83 (SE 0.044 ) of this microbial $\mathbf{N}$ flowing from the caecum appeared in faecal NU-NAN (Table 3).

\section{Infusion of $\left[{ }^{15} N\right]$ urea into the blood}

The build-up of ${ }^{15} \mathrm{~N}$ tracer concentration with time is shown for one sheep in Fig. $1(b)$. The rate of irreversible loss of $\mathrm{N}$ from the blood urea pool was 14.0 (SE 0.87$) \mathrm{g} \mathrm{N} / \mathrm{d}$, and 0.12 (SE 0.013 ) of rumen digesta $\mathrm{NH}_{3}-\mathrm{N}$ was derived from blood urea $\mathrm{N}$ (Table 4). The 

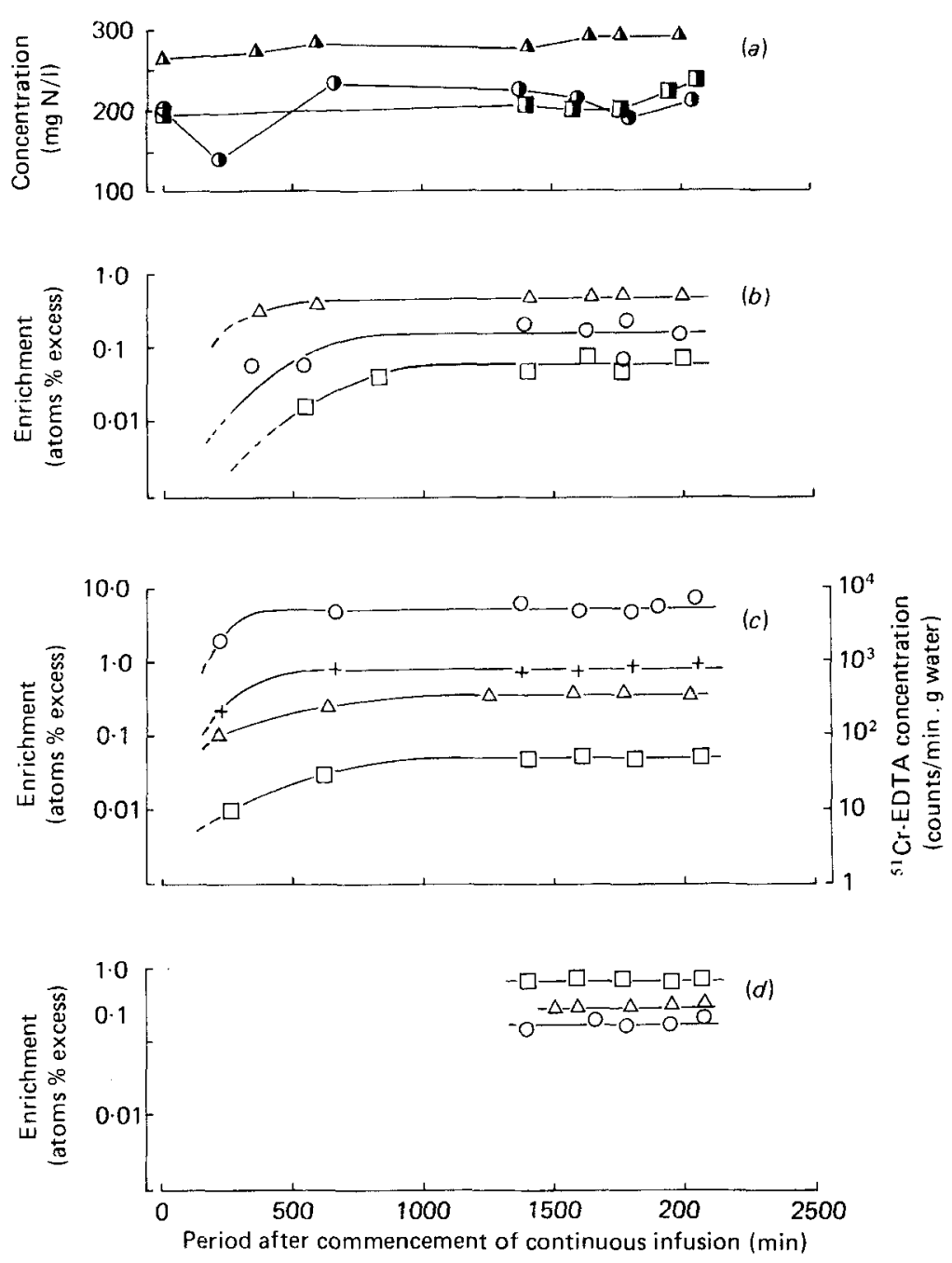

Fig. 1. (a) The concentrations (mg nitrogen/l) of blood urea-N ( $\mathbf{\Lambda})$, caecal digesta ammonia $(\mathbf{O})$ and rumen digesta $\mathrm{NH}_{3}(\mathbb{C})$ in one sheep when each pool was the primary pool for ${ }^{15} \mathrm{~N}$ tracer infusion. The enrichments (atom \% excess) of blood urea- $\mathrm{N}(\triangle)$, caecal digesta $\mathrm{NH}_{3}-\mathrm{N}(\mathrm{O})$ and rumen digesta $\mathrm{NH}_{3}-\mathrm{N}$ ( $\square$ ) for one sheep $(b)$ during continuous infusion $\left(5 \mathrm{mg}\right.$ atoms $\left.{ }^{15} \mathrm{~N} / \mathrm{d}\right)$ of $\left[{ }^{15} \mathrm{~N}\right] \mathrm{urea}$ into the blood and during continuous infusions $\left(5 \mathrm{mg}\right.$ atoms $\left.{ }^{15} \mathrm{~N} / \mathrm{d}\right)$ of $\left({ }^{15} \mathrm{NH}_{4}\right)_{2} \mathrm{SO}_{4}(c)$ into the caecum and $(d)$ into the rumen. The concentration (counts/min per $\mathrm{g}$ water) of ${ }^{51} \mathrm{Cr}$-EDTA in caecal digesta $(+)$ during infusion (/d) of $1.44 \times 10^{6}$ counts $/ \mathrm{min}$ of ${ }^{51} \mathrm{Cr}$-EDTA into the caecum.

proportion of the caecal digesta $\mathrm{NH}_{3}-\mathrm{N}$ pool derived from blood urea ranged widely among sheep from 0.19 to 0.60 with a mean of 0.38 (Table 4).

\section{Infusion of $\left({ }^{15} \mathrm{NH}_{4}\right)_{2} \mathrm{SO}_{4}$ into the rumen}

The ${ }^{15} \mathrm{~N}$ tracer concentration with time for one sheep is shown in Fig. 1(d). The rate of irreversible loss from the rumen digesta $\mathrm{NH}_{3}-\mathrm{N}$ pool was 9.29 (SE 0.645 ) g N/d, and the proportions of blood urea and caecal digesta $\mathrm{NH}_{3}-\mathrm{N}$ derived from rumen digesta $\mathrm{NH}_{3}-\mathrm{N}$ were 0.41 (SE 0.021) and 0.25 (SE 0.012) respectively (Table 5). 
Table 3. Expts 3 and 4. Measurements of caecal ammonia-nitrogen, rumen, blood urea- $N$ and caecal microbial $\mathrm{N}$ kinetics measured during continuous infusions of $\left({ }^{15} \mathrm{NH}_{4}\right)_{2} \mathrm{SO}_{4}$ into the caecum in three sheep, two of which were measured twice

(Mean values with their standard errors)

\begin{tabular}{|c|c|c|}
\hline Measurement & Mean & SE \\
\hline $\begin{array}{l}\text { Rate of irreversible loss from the caecal } \\
\text { digesta } \mathrm{NH}_{3}-\mathrm{N} \text { pool }(\mathrm{g} \mathrm{N} / \mathrm{d})\end{array}$ & $2 \cdot 17$ & 0.623 \\
\hline $\begin{array}{l}\text { Proportion of blood urea- } \mathrm{N} \text { derived from } \\
\text { caecal digesta } \mathrm{NH}_{3}-\mathrm{N}\end{array}$ & $0 \cdot 10$ & $0 \cdot 031$ \\
\hline $\begin{array}{l}\text { Proportion of rumen digesta } \mathrm{NH}_{3}-\mathrm{N} \text { derived } \\
\text { from caecal digesta } \mathrm{NH}_{3}-\mathrm{N}\end{array}$ & 0.012 & 0.0041 \\
\hline $\begin{array}{l}\text { Proportion of rumen bacterial } \mathrm{N} \text { derived from } \\
\text { caecal digesta } \mathrm{NH}_{3}-\mathrm{N}\end{array}$ & 0.005 & $0 \cdot 0009$ \\
\hline $\begin{array}{l}\text { Proportion of caecal digesta } \mathrm{NH}_{3}-\mathrm{N} \text { absorbed from } \\
\text { the large intestine transferred to blood urea }\end{array}$ & 0.92 & 0.054 \\
\hline $\begin{array}{l}\text { Caecal digesta } \mathrm{NH}_{3}-\mathrm{N} \text { flowing to the colon } \\
\text { in water }(\mathrm{g} \mathrm{N} / \mathrm{d})\end{array}$ & $0 \cdot 70$ & $0 \cdot 150$ \\
\hline $\begin{array}{l}\text { Caecal digesta } \mathrm{NH}_{3}-\mathrm{N} \text { flowing to the colon } \\
\text { as microbial } \mathrm{N}(\mathrm{g} \mathrm{N} / \mathrm{d})\end{array}$ & 0.56 & $0 \cdot 306$ \\
\hline Caecal NU-NAN flowing to the colon $(\mathrm{g} \mathrm{N} / \mathrm{d})$ & $6 \cdot 0$ & 1.06 \\
\hline Caecal microbial $\mathrm{N}$ flowing to the colon $(\mathrm{g} \mathrm{N} / \mathrm{d})$ & $2 \cdot 9$ & $0 \cdot 52$ \\
\hline $\begin{array}{l}\text { Proportion of caecal microbial } \mathrm{N} \text { apparently } \\
\text { derived from caecal digesta } \mathrm{NH}_{3}-\mathrm{N}^{*}\end{array}$ & $0 \cdot 17$ & $0 \cdot 064$ \\
\hline Faecal NU-NAN enrichment: caecal NU-NAN enrichment & $0 \cdot 83$ & $0 \cdot 044$ \\
\hline
\end{tabular}

NU-NAN: non-urea, non-ammonia-nitrogen.

* This value underestimates the proportion of caecal microbial $\mathrm{N}$ actually derived from caecal digesta $\mathrm{NH}_{3}-\mathrm{N}$ by the proportion of caecal microbial $\mathrm{N}$ consisting of undigested rumen microbial debris.

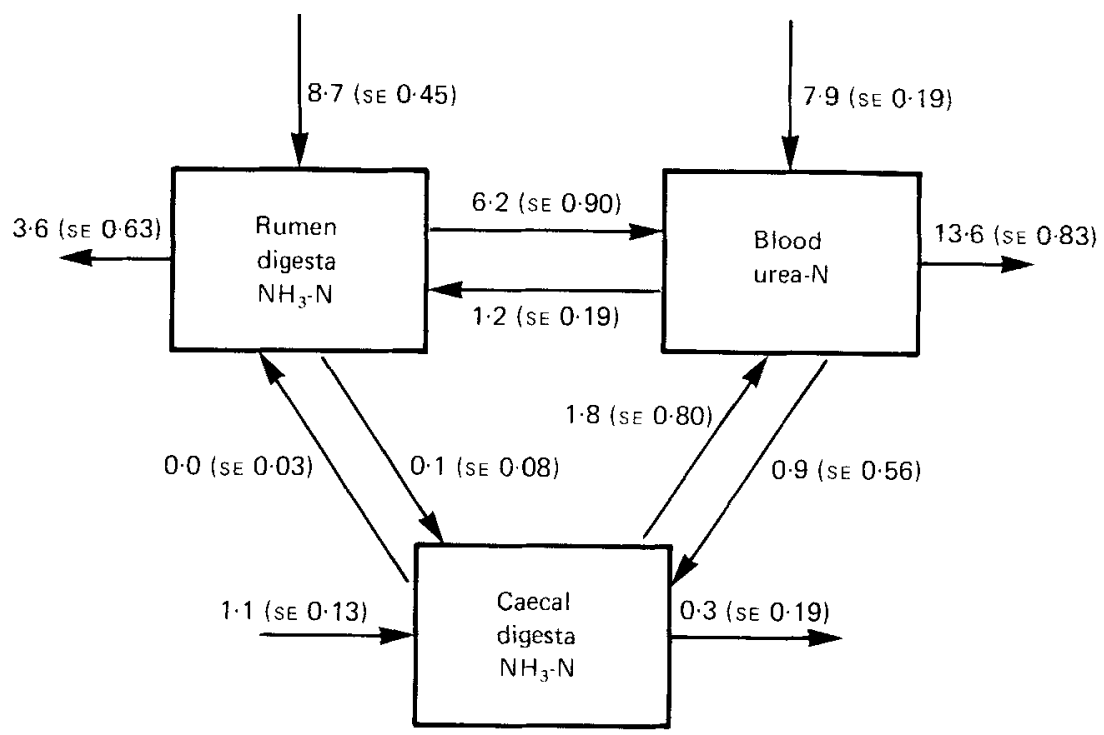

Fig. 2. An open-compartment model of flows of nitrogen $(\mathrm{g} \mathrm{N} / \mathrm{d})$ between the pools of rumen digesta ammonia-N, blood urea-N and caecal digesta $\mathrm{NH}_{3}-\mathrm{N}$. Values are means with their standard errors for individual solutions of the model for each of the three sheep. 
Table 4. Expts 1 and 2. Measurements of blood urea-nitrogen kinetics measured during four continuous infusions of $\left[{ }^{14} \mathrm{C}\right]$ urea and $\left[{ }^{15} \mathrm{~N}\right]$ urea into the blood and by total collection of urine from three sheep

(Mean values with their standard errors)

\begin{tabular}{|c|c|c|c|}
\hline Measurement & Mean & $\mathrm{SE}$ & $\begin{array}{c}\text { Statistical } \\
\text { significance } \\
\text { of difference } \dagger ; P<\end{array}$ \\
\hline \multicolumn{4}{|l|}{$\begin{array}{l}\text { Rate of irreversible loss from the blood } \\
\text { urea pool }(\mathrm{g} \mathrm{N} / \mathrm{d}) \text { determined with: }\end{array}$} \\
\hline$\left[{ }^{14} \mathrm{C}\right]$ urea & $17 \cdot 1$ & $1 \cdot 18\}$ & \multirow{4}{*}{$0 \cdot 01$} \\
\hline$\left[{ }^{15} \mathrm{~N}\right]$ urea & $14 \cdot 0$ & $0.87\}$ & \\
\hline $\begin{array}{l}\text { Proportion of caecal digesta ammonia-N } \\
\text { derived from blood urea }\end{array}$ & 0.38 & $0 \cdot 120$ & \\
\hline $\begin{array}{l}\text { Proportion of rumen digesta ammonia-N } \\
\text { derived from blood urea }\end{array}$ & $0 \cdot 12$ & $0 \cdot 013$ & \\
\hline \multicolumn{4}{|l|}{$\begin{array}{l}\text { Blood urea transfer to the rumen digesta } \\
(\mathrm{g} \mathrm{N} / \mathrm{d}) \text { : }\end{array}$} \\
\hline${ }^{14} \mathrm{C}$ tracers & $1 \cdot 7$ & $0 \cdot 15$ & \multirow{2}{*}{0.05} \\
\hline${ }^{15} \mathrm{~N}$ tracers & $1 \cdot 2$ & $0 \cdot 19$ & \\
\hline \multicolumn{4}{|l|}{$\begin{array}{l}\text { Blood urea transfer to the caecal digesta } \\
(\mathrm{g} \mathrm{N} / \mathrm{d}) \text { : }\end{array}$} \\
\hline${ }^{14} \mathrm{C}$ tracers & $1 \cdot 4$ & $0.61\}$ & \multirow{2}{*}{$0 \cdot 01$} \\
\hline${ }^{15} \mathrm{~N}$ tracers & 0.9 & $0.56\}$ & \\
\hline Urinary urea excretion $(\mathrm{g} \mathrm{N} / \mathrm{d})$ & $10 \cdot 1$ & $0 \cdot 34$ & \\
\hline \multicolumn{4}{|l|}{$\begin{array}{l}\text { Blood urea transfer to the gastrointestinal } \\
\text { tract other than the rumen digesta and the } \\
\text { caecal digesta }(\mathrm{g} \mathrm{N} / \mathrm{d})^{*} \text { : }\end{array}$} \\
\hline${ }^{14} \mathrm{C}$ tracers & $3 \cdot 9$ & $1.37 \mid$ & \multirow{2}{*}{0.05} \\
\hline${ }^{15} \mathrm{~N}$ tracers & $4 \cdot 8$ & $1.32\}$ & \\
\hline
\end{tabular}

* Calculated as the rate of irreversible loss estimated with $\left[{ }^{14} \mathrm{C}\right]$ urea minus urea transfer to the rumen and the caecum minus urinary urea excretion.

$\uparrow$ Compared using a $t$ test paired for measurements made within each sheep and twice for one sheep.

Table 5. Expt 7. The rate of irreversible loss of rumen digesta ammonia-nitrogen and the proportions of the $N$ in various secondary pools derived from rumen digesta ammonia- $N$ estimated by continuous infusion of $\left({ }^{15} \mathrm{NH}_{4}\right)_{2} \mathrm{SO}_{4}$ into the rumen of each of three sheep

(Mean values with their standard errors)

\begin{tabular}{|c|c|c|}
\hline Measurement & Mean & $\mathrm{SE}$ \\
\hline $\begin{array}{l}\text { Rate of irreversible loss from the rumen } \\
\text { digesta } \mathrm{NH}_{3}-\mathrm{N} \text { pool }(\mathrm{g} \mathrm{N} / \mathrm{d})\end{array}$ & $9 \cdot 29$ & 0.645 \\
\hline $\begin{array}{l}\text { Proportion of rumen bacterial } \mathrm{N} \text { derived } \\
\text { from rumen digesta } \mathrm{NH}_{3}-\mathrm{N}\end{array}$ & 0.41 & 0.021 \\
\hline $\begin{array}{l}\text { Proportion of blood urea-N derived from } \\
\text { rumen digesta } \mathrm{NH}_{3}-\mathrm{N}\end{array}$ & 0.41 & 0.027 \\
\hline $\begin{array}{l}\text { Proportion of caecal } \mathrm{NH}_{3}-\mathrm{N} \text { derived } \\
\text { from rumen digesta } \mathrm{NH}_{3}-\mathrm{N}\end{array}$ & 0.25 & 0.012 \\
\hline $\begin{array}{l}\text { Proportion of caecal microbial } \mathrm{N} \text { apparently } \\
\text { derived from rumen digesta } \mathrm{NH}_{3}-\mathrm{N}\end{array}$ & $0 \cdot 18$ & 0.009 \\
\hline $\begin{array}{l}\text { Proportion of caecal NU-NAN apparently } \\
\text { derived from rumen digesta } \mathrm{NH}_{3}-\mathrm{N}\end{array}$ & $0 \cdot 13$ & $0 \cdot 015$ \\
\hline
\end{tabular}



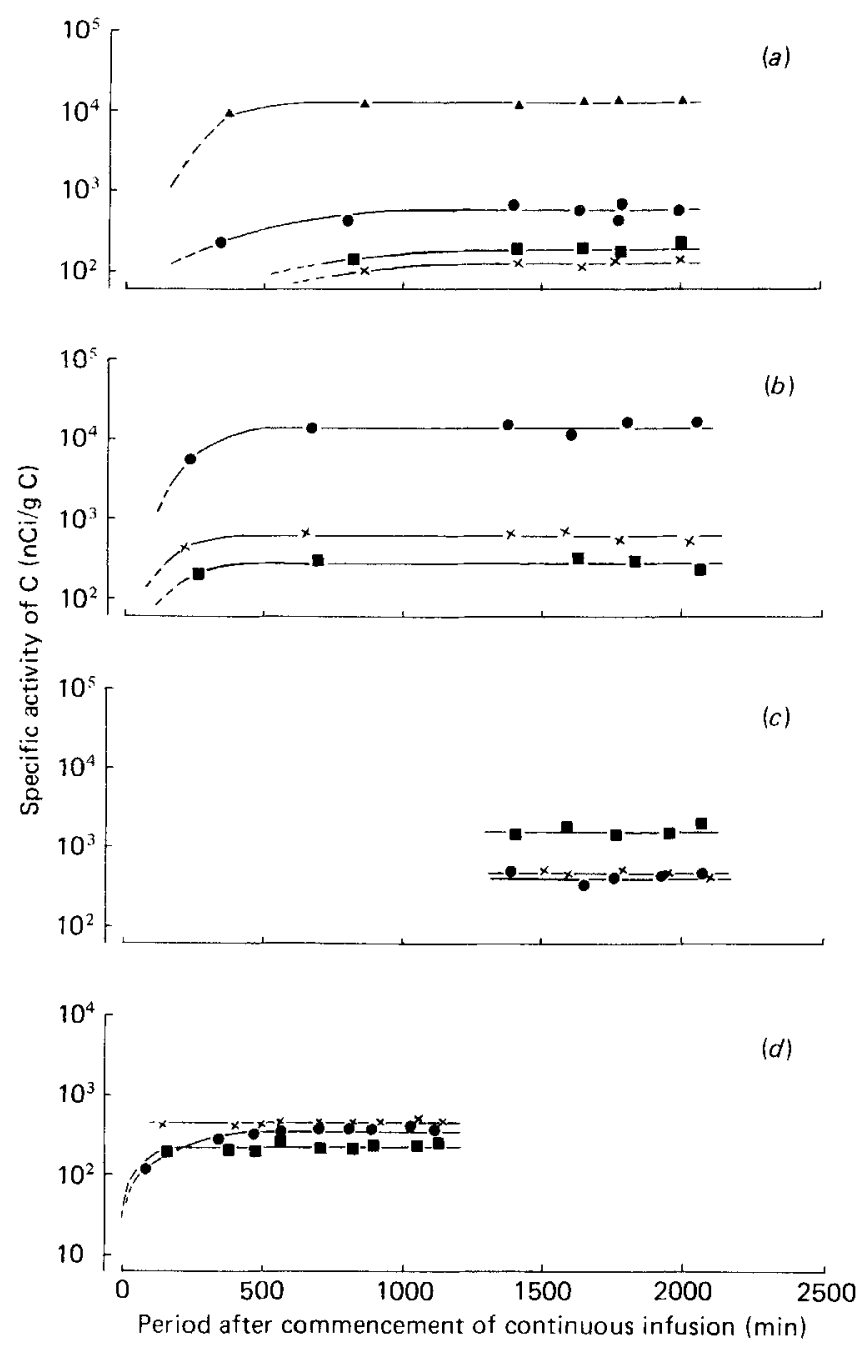

Fig. 3. The specific radioactivity of blood urea-carbon $(\boldsymbol{A})$, caecal digesta bicarbonate-C ( $\boldsymbol{O})$, rumen digesta bicarbonate-C $(\square)$ and jugular vein blood bicarbonate-C $(\mathbf{X})$ in one sheep $(a)$ during infusion $(100 \mu \mathrm{Ci} / \mathrm{d})$ of $\left[{ }^{14} \mathrm{C}\right]$ urea into the blood, and during infusion $(100 \mu \mathrm{Ci} / \mathrm{d})$ of $\mathrm{H}^{14} \mathrm{CO}_{3}$ into $(b)$ the caecum, (c) rumen or $(d)$ jugular vein.

\section{Three-pool model of $N$ flows derived from ${ }^{15} \mathrm{~N}$ tracer results}

The three-pool model of mean $\mathrm{N}$ flows is shown in Fig. 2.

The production of $\mathrm{NH}_{3}-\mathrm{N}$ by proteolysis and deamination of endogenous $\mathrm{N}$ and undigested dietary $\mathrm{N}$ was $1 \cdot 1$ (SE 0.13 ) g N/d. Transfer of $\mathrm{NH}_{3}-\mathrm{N}$ to the caecal digesta pool from the rumen digesta $\mathrm{NH}_{3}$ pool was 0.1 (SE 0.08 ) g N/d. Since the enrichment of rumen bacterial $\mathrm{N}$ was only 0.41 of that of rumen digesta $\mathrm{NH}_{3}-\mathrm{N}$ (Table 5), while the model estimated the $\mathrm{N}$ flow from the rumen digesta $\mathrm{NH}_{3}-\mathrm{N}$ to the caecal digesta $\mathrm{NH}_{3}-\mathrm{N}$ pools, the actual degradation of rumen microbial $\mathrm{N}$ was 2.4 times this flow, i.e. $0.3 \mathrm{~g} \mathrm{~N} / \mathrm{d}$. Transfer of blood urea- $\mathrm{N}$ to the caecal digesta $\mathrm{NH}_{3}$ pool was 0.9 (SE 0.56 ) g N/d and hence tended to be less than the transfer to the rumen $(1 \cdot 2$ (SE 0.19) $\mathrm{g} \mathrm{N} / \mathrm{d}$; Fig. 2).

Caecal digesta $\mathrm{NH}_{3}$ entering the blood urea pool by absorption from the large intestine 


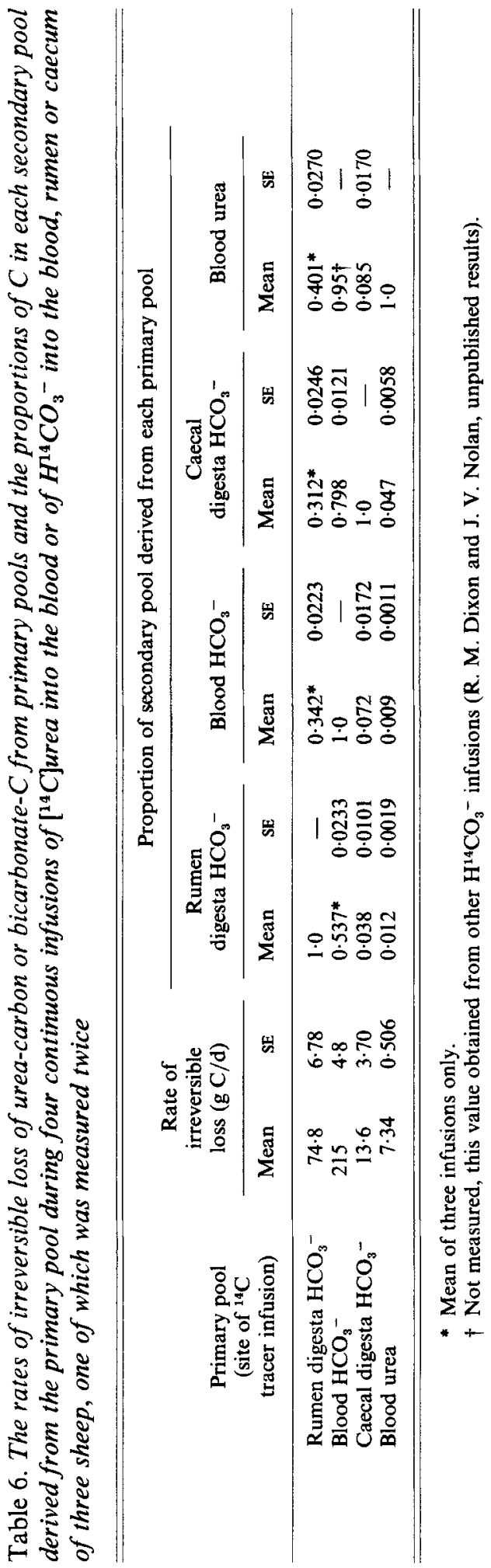




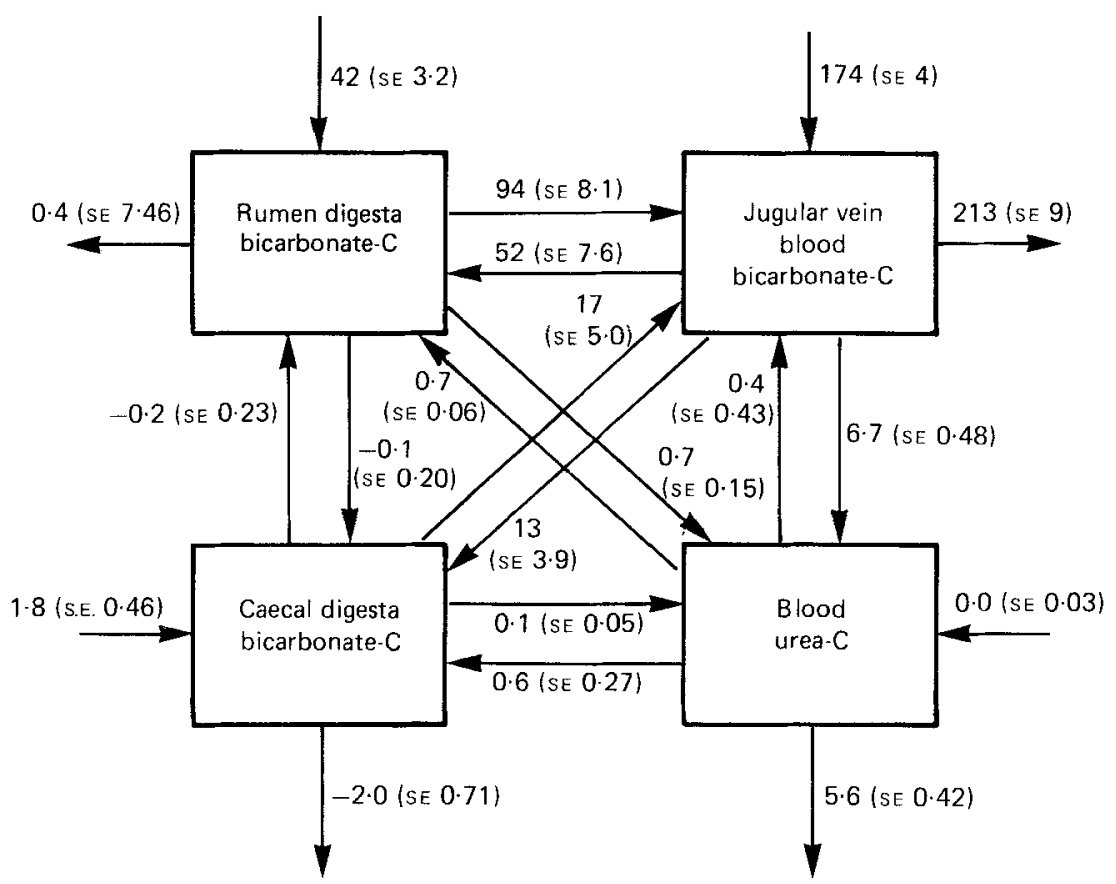

Fig. 4. An open-compartment model of flows of carbon $(\mathrm{g} \mathrm{C} / \mathrm{d})$ between the pools of rumen digesta bicarbonate-C, jugular vein blood bicarbonate- $C$, caecal digesta bicarbonate- $C$ and blood urea-C. Values are means with their standard errors for individual solutions of the model for each of the three sheep.

was $2 \cdot 2(\mathrm{SE} 0 \cdot 7) \mathrm{g} \mathrm{N} / \mathrm{d}$. Direct transfer of caecal digesta $\mathrm{NH}_{3}-\mathrm{N}$ to rumen digesta $\mathrm{NH}_{3}-\mathrm{N}$ was negligible, indicating that caecal digesta $\mathrm{NH}_{3}$ was transferred to the rumen only via the blood urea pool.

\section{Continuous infusion of ${ }^{14} \mathrm{C}$ tracers into the caecal, blood and rumen bicarbonate pools and into the blood urea pool}

The build-up of ${ }^{14} \mathrm{C}$ tracer concentrations with time in primary and secondary pools during infusions of tracer into the various sites in one sheep are shown in Fig. 3, and the rates of irreversible loss from each primary pool and the proportion of each secondary pool derived from each primary pool are given in Table 6. The four-pool model of $\mathrm{C}$ flows representing all sheep is given in Fig. 4.

Bicarbonate- $\mathrm{C}$ derived from fermentation of substrate in the caecal digesta was 1.8 (SE 0.46$) \mathrm{g} \mathrm{C} / \mathrm{d}$, or $4 \%$ of the production in the rumen digesta. There were large flows of bicarbonate- $\mathrm{C}$ in both directions between the blood bicarbonate and the caecal digesta bicarbonate pools, as well as between the blood bicarbonate and the rumen digesta bicarbonate pools.

The transfer of blood urea-C to the caecal digesta bicarbonate pool was 0.6 (SE $0.27) \mathrm{g} \mathrm{C} / \mathrm{d}$, and transfer of blood urea-C to the rumen digesta bicarbonate pool was 0.7 (SE 0.15) g C/d (Fig. 4).

\section{Comparison of the results obtained with ${ }^{15} \mathrm{~N}$ and ${ }^{14} \mathrm{C}$ tracers}

The estimate of the rate of irreversible loss from the blood urea pool was greater $(P<0.01)$ when measured with $\left[{ }^{14} \mathrm{C}\right]$ urea $(17 \cdot 1 \mathrm{~g} \mathrm{~N} / \mathrm{d})$ than with $\left[{ }^{15} \mathrm{~N}\right]$ urea $(14.0 \mathrm{~g} \mathrm{~N} / \mathrm{d})$ (Table 4).

The estimates of transfer of blood urea measured with ${ }^{14} \mathrm{C}$ tracers to the caecal digesta 


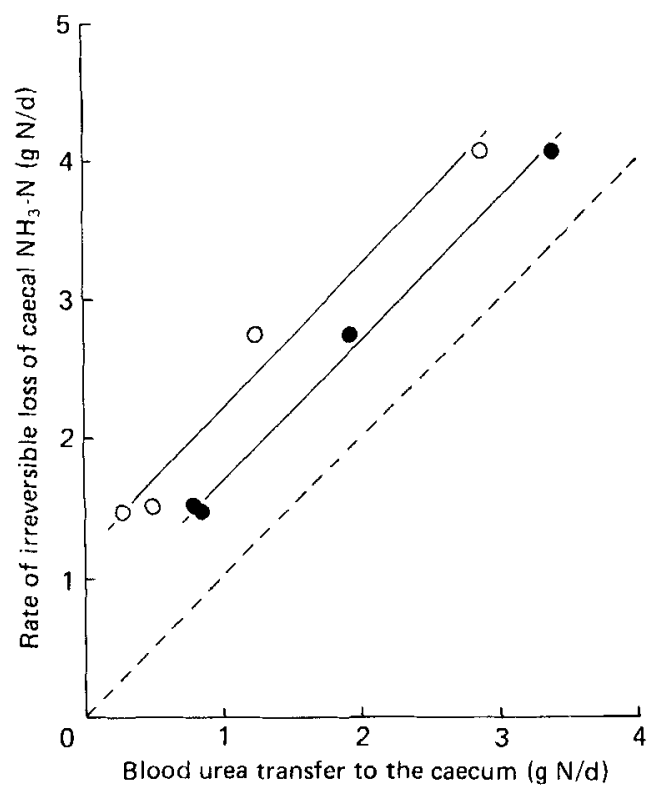

Fig. 5. The relations between the rate of irreversible loss of ammonia-nitrogen from the caecal digesta pool $(Y)$ and the apparent transfer of blood urea into the caecum measured in the three-pool model of $\mathrm{N}$ flows in Fig. 2. $\left(X_{\mathrm{N}}, \mathrm{O}\right)$, or the four-pool model of $\mathrm{C}$ flows in Fig. $4\left(X_{\mathrm{C}},-\right)$. The regression equations are:

$$
\begin{gathered}
Y=1.18+1.04(\text { SE } 0.124) X_{\mathrm{N}} \quad(\mathrm{r} 0.99, \text { residual SD (RSD) } 0.258, P<0.05, n 4) \\
Y=0.67+1.02(\text { SE } 0.056) X_{\mathrm{C}} \quad(r 0.99, \text { RSD } 0.112, P<0.01, n 4)
\end{gathered}
$$

The relation (---) was that expected if all urea entering the caecal digesta were hydrolysed to ammonia-N. Measurements were made once in sheep B and C and twice in sheep A (see Table 2); the two highest values are for sheep $A$.

and the rumen digesta were greater than these estimates of transfer of blood urea measured with ${ }^{15} \mathrm{~N}$ tracers $(P<0.01, P<0.05$ respectively; Table 4$)$. Urea hydrolysis in the gastrointestinal tract that did not enter the rumen digesta and the caecal digesta pools accounted for $4.8 \mathrm{~g} \mathrm{~N} / \mathrm{d}$ or 0.69 of the total urea hydrolysis when measured with ${ }^{15} \mathrm{~N}$ tracers, or $3.9 \mathrm{~g} \mathrm{~N} / \mathrm{d}$ or 0.56 of total urea hydrolysis when measured with ${ }^{14} \mathrm{C}$ tracers (Table 4 ).

The relations between the rate of irreversible loss of $\mathrm{NH}_{3}-\mathrm{N}$ from the caecal digesta pool and the rate of transfer of blood urea into the caecal digesta measured with either ${ }^{14} \mathrm{C}$ or ${ }^{15} \mathrm{~N}$ tracers were different in elevation $(P<0.05)$, while the slopes were identical to that expected on the basis that $1 \mathrm{~mol}$ urea is hydrolysed to $2 \mathrm{~mol} \mathrm{NH}_{3}-\mathrm{N}$ (Fig. 5). The concentration of caecal digesta $\mathrm{NH}_{3}-\mathrm{N}$ and the apparent transfer of blood urea to the caecal digesta measured with either ${ }^{15} \mathrm{~N}$ or ${ }^{14} \mathrm{C}$ tracers also tended $(P>0.05)$ to be related $(r 0.84$, $r 0.79$ respectively; $n 4)$.

\section{Total collection of faeces and urine}

Apparent digestibility of organic matter was 0.58 (SE 0.006). Urinary total $\mathrm{N}$ excretion was 12.1 (SE 0.44$) \mathrm{g} \mathrm{N} / \mathrm{d}$, of which 10.1 (SE 0.34 ) g N/d consisted of urea- $\mathrm{N}$. Of the intake of $20.4 \mathrm{~g} \mathrm{~N} / \mathrm{d}, 1 \cdot 7(\mathrm{SE} 0 \cdot 17) \mathrm{g} \mathrm{N} / \mathrm{d}$ was retained. 


\section{DISCUSSION}

\section{The reliability of the quantitative models}

Consideration of concentration in the caecal digesta $\mathrm{NH}_{3}-\mathrm{N}$, rumen digesta $\mathrm{NH}_{3}-\mathrm{N}$ and blood urea $\mathrm{N}$ pools (Table 2) suggested that metabolic steady-state conditions were satisfactorily achieved within the individual sheep used to provide the data for the three-pool and four-pool models. Differences between successive infusions in individual sheep measured over several weeks were small, and during most infusions there was no change $(P>0.05)$ in concentration of $\mathrm{NH}_{3}-\mathrm{N}$ or urea with time. This suggested that error resulting from metabolic differences between experiments was likely to be minor. The variability associated with measurements of caecal pools was, as expected from previous marker experiments, greater than in the rumen but was unlikely to have introduced bias (Dixon et al. 1982).

The open-compartment model used in the present study provided a complete quantitative description of the flows between the sampled pools during an experiment, but it must be recognized that the estimated flow includes transfer of the traced substance by all possible pathways (Nolan et al. 1976; Nolan \& Rowe, 1976). For example, the pathways for flow of $\mathrm{N}$ from the caecal digesta $\mathrm{NH}_{3}$ to blood pools in Fig. 2 may have included (1) $\mathrm{NH}_{3}-\mathrm{N}$ which was absorbed directly through the caecal wall and converted immediately to urea, (2) $\mathrm{NH}_{3}-\mathrm{N}$ which flowed out of the caecal digesta pool to the colon as $\mathrm{NH}_{3}-\mathrm{N}$ or microbial $\mathrm{N}$, was absorbed as $\mathrm{NH}_{3}-\mathrm{N}$ or amino acids and subsequently converted to urea and (3) caecal digesta $\mathrm{NH}_{3}-\mathrm{N}$ incorporated into non-essential amino acids in the liver and which were subsequently deaminated and the amino- $\mathrm{N}$ converted to urea. Consequently, care must be taken with the interpretation of the measured flows and additional information is needed to indicate major pathways.

The extent to which flows through the sampled caecal digesta pool indicated the total flows of $\mathrm{NH}_{3}-\mathrm{N}$ through the caecum and proximal colon has been discussed previously (Dixon \& Nolan, 1983; Dixon \& Milligan, 1984); in these experiments the production of $\mathrm{NH}_{3}-\mathrm{N}$ by proteolysis and deamination in the caecal digesta pool accounted for 0.76 and 0.60 of the $\mathrm{NH}_{3}-\mathrm{N}$ production in the digesta of the entire caecum and proximal colon in sheep given lucerne and bromegrass (Bromus inermus) respectively. Hence the measurements of flow through the sampled digesta $\mathrm{NH}_{3}-\mathrm{N}$ and digesta bicarbonate-C pools in the present experiments would have underestimated the production in the digesta of the entire caecum and proximal colon.

As expected the estimate of $\mathrm{NH}_{3}-\mathrm{N}$ production from sources of $\mathrm{N}$ other than urea in the caecal digesta pool in the three-pool model $(1 \cdot 1+0 \cdot 1=1 \cdot 12 \mathrm{~g} \mathrm{~N} / \mathrm{d} ;$ Fig. 2) was similar to that obtained from the $Y$-intercept of the regression line when no $\left[{ }^{15} \mathrm{~N}\right] \mathrm{urea}-\mathrm{N}$ apparently entered the caecal $\mathrm{NH}_{3}-\mathrm{N}$ pool $(1 \cdot 17 \mathrm{~g} \mathrm{~N} / \mathrm{d}$; Fig. 5). This was to be expected since the latter value is that part of the rate of irreversible loss of the caecal digesta $\mathrm{NH}_{3}-\mathrm{N}$ pool which could not be attributed to the hydrolysis of blood urea. However, the estimated transfer of blood urea to the caecal digesta pool depended on both the estimates of the proportion of the caecal digesta $\mathrm{NH}_{3}-\mathrm{N}$ or caecal digesta bicarbonate- $\mathrm{C}$ pools derived from the blood urea made during the tracer infusion into the blood urea pool, and the rate of irreversible loss when caecal digesta was the primary pool, whereas the estimate of the rate of irreversible loss of caecal digesta $\mathrm{NH}_{3}-\mathrm{N}$ depended on the infusion into the caecal pool. Hence the linearity of the relation between the rate of irreversible loss from the caecal digesta $\mathrm{NH}_{3}-\mathrm{N}$ pool and urea transfer to the caecal pool when measured by either tracer suggested that differences in the urea transfer to the caecal pool were actual differences among sheep and that constant conditions prevailed when the same sheep was studied on different experimental 
days. Furthermore, the slope of the regression lines was that expected on the basis that each mol blood urea is hydrolysed to $2 \mathrm{~mol} \mathrm{NH}_{3}$.

\section{Comparison of ${ }^{15} \mathrm{~N}$ and ${ }^{14} \mathrm{C}$ tracer techniques for measurement of urea kinetics}

The lower rate of irreversible loss of $\left[{ }^{15} \mathrm{~N}\right]$ urea than of $\left[{ }^{14} \mathrm{C}\right]$ urea (Table 4) was expected, and the latter measurement should be the better estimate of total flux of urea through the blood pool (Nolan \& Stachiw, 1979; Dixon \& Milligan, 1984). The greater estimate of blood urea transfer to the caecal digesta pool with ${ }^{14} \mathrm{C}$ than with ${ }^{15} \mathrm{~N}$ (Table 4 ) provides an explanation for the differences in elevation of the two regression lines shown in Fig. 5.

The estimated transfer of blood urea to the caecal digesta or rumen digesta measured in the open-compartment models with either ${ }^{14} \mathrm{C}$ or ${ }^{15} \mathrm{~N}$ tracers would have been increased if $\mathrm{H}^{14} \mathrm{CO}_{3}{ }^{-}$or ${ }^{15} \mathrm{NH}_{4}{ }^{+}$produced outside the relevant pool entered it without passing through the blood bicarbonate- $\mathrm{C}$ pool or the urea pool. Furthermore, the rate of reabsorption of each would be likely to differ depending on the $\mathrm{pH}$ and the respective dissociation constants. In the ileum, with a pH 7-8 (Dixon \& Nolan, 1982), $\mathrm{H}^{14} \mathrm{CO}_{3}^{-}$was likely to remain in the digesta and hence flow into the caecum, whereas ${ }^{15} \mathrm{NH}_{4}{ }^{+}$was likely to be absorbed rapidly. Rapid absorption of $\mathrm{NH}_{3}-\mathrm{N}$ from the ileum has been observed in other species (Mossberg $\&$ Ross, 1967). Consequently the finding that transfer to the caecal digesta of blood urea when measured with ${ }^{14} \mathrm{C}$ tracers was 0.52 greater than when measured with ${ }^{15} \mathrm{~N}$ tracers may have been the result of differential rates of absorption of the products of urea hydrolysis in the small intestine and, therefore, different flows of these products to the caecal digesta pool via the ileum. Furthermore, observations in the present experiments that caecal digesta bicarbonate SR tended to be maintained for some time after the termination of the infusion of $\mathrm{H}^{14} \mathrm{CO}_{3}{ }^{-}$into the blood, as it would if a considerable proportion of blood bicarbonate entered the caecum via ileal digesta, supported this hypothesis. Similarly $\mathrm{H}^{14} \mathrm{CO}_{3}{ }^{-}$from hydrolysis of salivary urea in the buccal regions and oesophagus (Kornberg et al. 1954) may have passed to the rumen in alkaline saliva while ${ }^{15} \mathrm{NH}_{4}{ }^{+}$was absorbed, and thus caused the apparent transfer of urea to the rumen to be 0.38 greater when measured with the ${ }^{14} \mathrm{C}$ than with the ${ }^{15} \mathrm{~N}$ tracers. In addition, blood urea hydrolysis may have occurred in or near the rumen wall and caecal wall with a greater proportion of the $\mathrm{H}^{14} \mathrm{CO}_{3}{ }^{-}$than of the ${ }^{15} \mathrm{NH}_{4}{ }^{+}$ thus produced entering the respective rumen or caecal digesta pool (Houpt, 1970; Allen \& Miller, 1976; Cheng \& Wallace, 1979). The proportions of the $\mathrm{H}^{14} \mathrm{CO}_{3}^{-}$and $\mathrm{NH}_{4}^{+}$ hydrolysis products which mixed with the rumen or caecal digesta pools or were absorbed into the blood may have differed depending on the respective dissociation constants and concentration gradients.

The different estimates obtained with ${ }^{14} \mathrm{C}$ and ${ }^{15} \mathrm{~N}$ tracers in the present experiment are in contrast to the results obtained by Nolan \& Stachiw (1979) with sheep given low-N diets where no significant difference was observed, and where transfer estimated with ${ }^{14} \mathrm{C}$ tracers even tended to be less than that estimated with ${ }^{15} \mathrm{~N}$ tracers. In choosing which tracer to use for similar studies, because $\mathrm{NH}_{3}-\mathrm{N}$ is the hydrolysis product of urea that is potentially useful for microbial $\mathrm{N}$ synthesis, ${ }^{15} \mathrm{~N}$ tracer results are likely to give a better indication of the availability of endogenous urea- $\mathrm{N}$ for microbial growth in the rumen or the caecum.

\section{Transfer of blood urea- $N$ to various sections of the gastrointestinal tract}

The transfer of blood urea into the caecal digesta (Table 4) could have occurred either via ileal digesta or by direct transfer across the caecal wall. In order to estimate the likely importance of endogenous urea entry to the caecum in ileal digesta, results obtained in previous acute experiments (Dixon \& Nolan, 1982; Dixon \& Milligan, 1984) were collated. Significant relations were observed between the concentration of urea- $\mathrm{N}+\mathrm{NH}_{3}-\mathrm{N}$ in ileal 


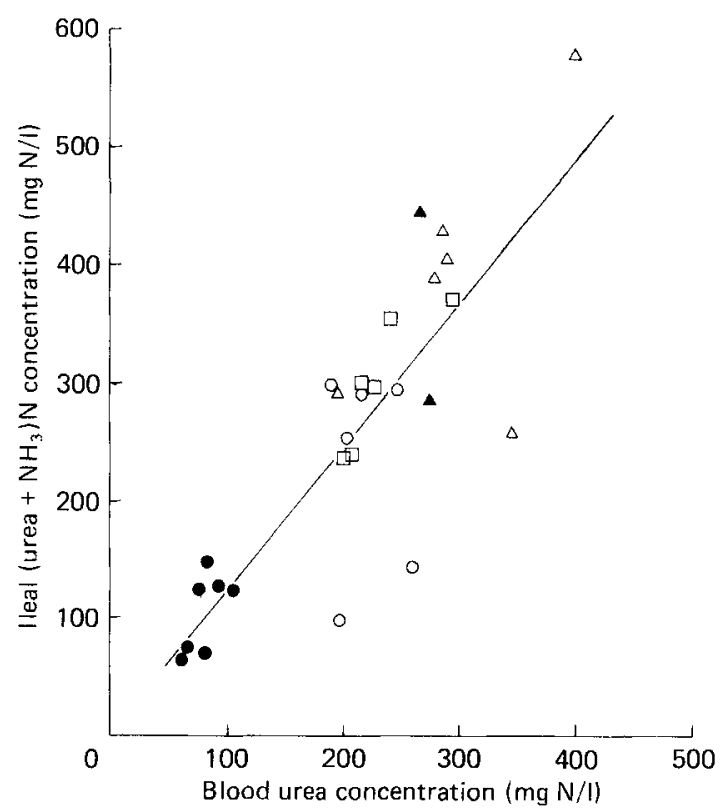

Fig. 6. The relation between ileal (urea + ammonia)-nitrogen concentration (mg N/1) and the blood urea concentration (mg N/1) measured in each of twenty-seven sheep given lucerne hay (Medicago sativa) $(\mathrm{O})$, bromegrass (Bromus inermus) hay $(\Theta)$, sugar-cane bagasse-sugar-based diets $(\triangle$ ), pelleted barley grain and urea $(\boldsymbol{A})$ or grazing Phalaris tuberosa - white clover (Trifolium repens) pasture $(\square)$. The equation of the regression is given by

$$
Y=1 \cdot 17+1 \cdot 23(\text { SE } 0 \cdot 159) X(r 0 \cdot 84 \text {, residual SD } 8 \cdot 50, P<0 \cdot 01, n 27) .
$$

digesta and the blood urea concentration (Fig. 6), and also the concentration of $\mathrm{NH}_{3}-\mathrm{N}$ in the caecum and proximal colon and the blood urea concentration; the latter relation is described by:

$$
Y=100+0.69(\text { SE } 0 \cdot 148) X \quad(r 0.68, \text { residual SD } 8 \cdot 21, P<0 \cdot 01, n 27),
$$

where $Y$ is the mean $\mathrm{NH}_{3}-\mathrm{N}$ concentration in the digesta of the caecum and proximal colon (mg $\mathrm{NH}_{3}-\mathrm{N} / \mathrm{l}$ ), and $X$ is the blood urea concentration ( $\mathrm{mg} \mathrm{N} / \mathrm{l}$ ). These results for sheep are in agreement with observations of transfer of blood urea into the small intestine in dogs (Hakim \& Lipson, 1964) and in sheep (Hecker, 1971 b; Boda et al. 1976). If the concentration of urea in ileal water and blood were equal, on the basis of estimates of ileal digesta flow in similar sheep (Dixon \& Nolan, 1982), up to $1.5 \mathrm{~g}$ urea-N/d could have entered the caecum in ileal digesta. In sheep $\mathrm{B}$ and $\mathrm{C} 0.27-0.86 \mathrm{~g}$ blood urea- $\mathrm{N}$ entered the caecal digesta $\mathrm{NH}_{3}-\mathrm{N}$ pool, and this transfer could have occurred entirely via ileal digesta. Estimates of transfer of blood urea into the caecal digesta pool of sheep A were 2.1 and $2.7 \mathrm{~g} \mathrm{~N} / \mathrm{d}$ for ${ }^{15} \mathrm{~N}$ and ${ }^{14} \mathrm{C}$ tracers respectively and, hence, there was apparently some transfer of blood urea across the caecal wall to the caecal digesta in this sheep. The likely absence of transfer of blood urea across the caecal wall into the caecal digesta pool in most instances agrees with measurements using ${ }^{15} \mathrm{~N}$ tracers in acute experiments with sheep given either lucerne or bromegrass hay (Dixon \& Nolan, 1983; Dixon \& Milligan, 1984) and with evidence of low transfer in perfusion experiments in humans (Billich \& Levitan, 1969; Wolpert et al. 1971). Nevertheless there is evidence that blood urea can pass across the caecal wall under some circumstances (Chalmers et al. 1976) and that the rate varies with diet 
(Engelhardt \& Hinderer, 1976). The mean transfer of blood urea into the caecal digesta $\mathrm{NH}_{3}$ pool by all routes measured with ${ }^{15} \mathrm{~N}$ tracers $(0.9 \mathrm{~g} \mathrm{~N} / \mathrm{d})$ was only slightly greater than the estimate of $0.67 \mathrm{~g} \mathrm{~N} / \mathrm{d}$ obtained in acute experiments (Dixon \& Nolan, 1983) and less than the estimate of $1.3 \mathrm{~g} \mathrm{~N} / \mathrm{d}$ obtained by Nolan et al. (1976) in sheep given lucerne hay. The wide range $(0 \cdot 19-0.60)$ in the proportion of caecal digesta $\mathrm{NH}_{3}-\mathrm{N}$ derived from blood urea- $\mathrm{N}$ is in accord with a wide range $(0.14-0.34)$ observed in the acute experiments of Dixon \& Nolan (1983). Also there were differences among sheep, with the two estimates in sheep A $(0.56$ and 0.64$)$ being greater $(P<0.05)$ than these estimates for sheep B and C $(0.34$ and 0.19 respectively).

In agreement with previous experiments with sheep given lucerne (Nolan \& Leng, 1972; Nolan et al. 1976; Kennedy \& Milligan, 1977), the hydrolysis of urea in the rumen digesta pool comprised only $0 \cdot 17-0.24$ of total urea hydrolysis. Urea hydrolysis in the gastrointestinal tract other than in the rumen and caecal digesta pools was 0.56 of total urea hydrolysis when determined with ${ }^{14} \mathrm{C}$ tracers, or 0.69 when determined with ${ }^{15} \mathrm{~N}$ tracers. This compares with the estimate of Nolan et al (1976) of 0.54. Appreciable hydrolysis of blood urea did not occur in the digesta of the distal colon of sheep in the experiments of Dixon \& Nolan (1983) and Dixon \& Milligan (1984), but did occur in the experiment of Nolan et al. (1976).

As discussed (p. 327), it is quite possible that blood urea did pass across the caecal wall or the rumen wall, or both, and that hydrolysis of this urea occurred in or near the wall without the resultant $\mathrm{H}^{14} \mathrm{CO}_{3}^{-}$or $\mathrm{NH}_{4}{ }^{+}$mixing with the respective sampled digesta pool. Much of the hydrolysis of urea other than in the caecal and rumen digesta pools may have occurred in such a manner. Alternatively the buccal regions, oesophagus, omasum, abomasum and small intestine may also be quantitatively important sites of urea hydrolysis.

\section{Production of $\mathrm{NH}_{3}-\mathrm{N}$ in the caecum}

The rate of irreversible loss of $\mathrm{NH}_{3}-\mathrm{N}$ from the caecal digesta pool for the three sheep in the present study $(2.17$ (SE 0.623$) \mathrm{g} \mathrm{N} / \mathrm{d}$ ) was somewhat less than the estimates of Dixon \& Nolan (1983) (3.2 (SE 0.49) g N/d) and Nolan et al. (1976) $(4 \cdot 2 \mathrm{~g} \mathrm{~N} / \mathrm{d})$, although the latter measurement was associated with a relatively large transfer of endogenous urea into the caecum. On the basis of recycling of $0.6 \mathrm{~g} \mathrm{~N} / \mathrm{d}$ measured by Nolan et al. (1976), the total flux rate of $\mathrm{NH}_{3}-\mathrm{N}$ through the digesta pool would have been slightly greater than this rate of irreversible loss. Since the caecal digesta $\mathrm{NH}_{3}-\mathrm{N}$ pool size was only approximately $88 \mathrm{mg} N$ (Dixon \& Nolan, 1983), the turnover of the pool was rapid.

The production of $\mathrm{NH}_{3}-\mathrm{N}$ in the caecum by proteolysis and deamination of non${ }^{15} \mathrm{~N}$-labelled endogenous and dietary $\mathrm{N}(1 \cdot 1$ (SE $0 \cdot 13) \mathrm{g} \mathrm{N} / \mathrm{d}$; Fig. 2) was less than the estimate from acute experiments (Dixon \& Nolan, 1983;2.3 g N/d) or that by Nolan et al. (1976) $(2 \cdot 1 \mathrm{~g} \mathrm{~N} / \mathrm{d})$ in sheep given lucerne hay, but was greater than that in sheep given bromegrass hay $(0.7 \mathrm{~g} \mathrm{~N} / \mathrm{d}$; Dixon \& Milligan, 1984). Whether or not there were real differences between the groups of sheep given lucerne could not be determined. Hecker (1971 a) demonstrated that there was extensive degradation of proteins in caecal digesta in vitro, indicating that the necessary levels of enzyme activity occur to account for extensive proteolysis and deamination. Furthermore, degradation in the caecum of endogenous soluble mucins has been demonstrated (Hecker, 1973). The negligible flow from the rumen digesta $\mathrm{NH}_{3}-\mathrm{N}$ pool direct to the caecal digesta $\mathrm{NH}_{3}-\mathrm{N}$ pool in the threepool $\mathrm{N}$ model (Fig. 2) suggested that little undigested rumen microbial $\mathrm{N}$ was degraded to $\mathrm{NH}_{3}-\mathrm{N}$ in the caecum.

\section{Utilization of caecal digesta $\mathrm{NH}_{3}-\mathrm{N}$}

If recycling of $\mathrm{N}$ to the caecal digesta $\mathrm{NH}_{3}-\mathrm{N}$ pool were $0.6 \mathrm{~g} \mathrm{~N} / \mathrm{d}$, as estimated by Nolan et al. (1976), the total flux through the caecal digesta $\mathrm{NH}_{3}-\mathrm{N}$ pool would have been 
$2 \cdot 17+0.6$, i.e. $2 \cdot 8 \mathrm{~g} \mathrm{~N} / \mathrm{d}$. Hence, since $0.70 \mathrm{~g} \mathrm{NH}_{3}-\mathrm{N} / \mathrm{d}$ flowed to the proximal colon in digesta and $0.56 \mathrm{~g} \mathrm{NH}_{3}-\mathrm{N} / \mathrm{d}$ was incorporated into caecal microbial $\mathrm{N}$ (Table 3), by difference $1.5 \mathrm{~g} \mathrm{NH}_{3}-\mathrm{N} / \mathrm{d}$ was absorbed directly through the caecal wall. This estimate of absorption was similar to that made in sheep given lucerne in acute experiments $(1.9 \mathrm{~g} \mathrm{~N} / \mathrm{d}$; Dixon \& Nolan, 1983). Rapid absorption of $\mathrm{NH}_{3}$ from the caecum has been observed (Hecker, 1971 b; Chalmers et al. 1976), probably due to the high $\mathrm{pH}$ in the caecum of sheep at least when given forage diets. Since virtually all the $0.70 \mathrm{~g} \mathrm{NH}_{3}-\mathrm{N} / \mathrm{d}$ flowing to the proximal colon in digesta would have been absorbed before reaching the rectum (Dixon \& Nolan, 1983), total $\mathrm{NH}_{3}-\mathrm{N}$ absorption from the large intestine of $\mathrm{NH}_{3}-\mathrm{N}$ of caecal origin was at least $2 \cdot 2 \mathrm{~g} \mathrm{NH}_{3}-\mathrm{N} / \mathrm{d}$.

In the present study, caecal digesta $\mathrm{NH}_{3}-\mathrm{N}$ contributed on average $0 \cdot 10$ of the blood urea pool (Table 3), a value similar to that $(0 \cdot 13)$ obtained in sheep given lucerne by Nolan $e t$ al. (1976) and that $(0 \cdot 14)$ by Dixon \& Nolan (1983). The proportion of absorbed caecal digesta $\mathrm{NH}_{3}-\mathrm{N}$ which entered the blood urea- $\mathrm{N}$ in the present study $(0 \cdot 92$, Table 3) and in the experiment of Dixon \& Nolan (1983) (0.83) was, however, much greater than that observed by Nolan et al. (1976) $(0 \cdot 30-0 \cdot 40)$. We can provide no definite explanation for this difference between experiments. However, since the $\mathrm{NH}_{3}-\mathrm{N}$ absorbed from the gut that was not synthesized into blood urea was presumably synthesized into non-essential amino acids, the more recent studies do suggest that, in sheep given a high- $\mathrm{N}$ forage diet, the contribution of caecal digesta $\mathrm{NH}_{3}-\mathrm{N}$ to synthesis of non-essential amino acids is not quantitatively important. The incorporation of only 0.64 of absorbed caecal $\mathrm{NH}_{3}-\mathrm{N}$ into blood urea in sheep given a forage diet of moderate $\mathrm{N}$ content (Dixon \& Milligan, 1984) does, however, suggest that at lower $\mathrm{N}$ intake the contribution of caecal $\mathrm{NH}_{3}-\mathrm{N}$ is of greater importance. In the present study, 0.41 of blood urea was derived from rumen digesta $\mathrm{NH}_{3}-\mathrm{N}$ (Table 5); consequently the caecum was of much lesser importance than the rumen in providing $\mathrm{NH}_{3}-\mathrm{N}$ for the synthesis of blood urea.

The principal contribution of the caecum to $\mathrm{N}$ retention by the ruminant is likely to be by provision of $\mathrm{NH}_{3}-\mathrm{N}$ for urea- $\mathrm{N}$ synthesis with recycling of this urea to the rumen and utilization of the $\mathbf{N}$ for microbial protein synthesis. In agreement with previous studies with sheep given high-N forage diets (Nolan \& Leng, 1972; Nolan et al. 1976; Kennedy \& Milligan, 1977), transfer of blood urea to the rumen digesta pool in the present study was equivalent to only $0 \cdot 06-0.08$ of $\mathrm{N}$ intake. However, if more extensive blood urea transfer to the rumen occurs under some circumstances (Kennedy \& Milligan,1980; Norton et al. 1982) this pathway may be of importance to the ruminant.

\section{Turnover and synthesis of microbial $N$ in the caecum}

The observations that 0.48 of the NU-NAN flowing from the caecum consisted of microbial $\mathrm{N}$, that $0.56 \mathrm{~g}$ caecal digesta $\mathrm{NH}_{3}-\mathrm{N} / \mathrm{d}$ was incorporated into caecal microbial $\mathrm{N}$ and that 0.83 of caecal microbial $\mathrm{N}$ was excreted in faeces (Table 3 ) were in agreement with previous experiments in sheep given lucerne $(0.57,0.6 \mathrm{~g} \mathrm{~N} / \mathrm{d}$ and 0.89 respectively; Dixon \& Nolan, $1983)$ or bromegrass hay $(0.49,0.4 \mathrm{~g} \mathrm{~N} / \mathrm{d}$ and 0.73 respectively; Dixon \& Milligan, 1984). The present study supports the concept that there is little net synthesis of microbial $\mathrm{N}$ in the large intestine, that approximately half the caecal digesta $\mathrm{N}$ is microbial $\mathrm{N}$ and that the majority of the microbial $\mathrm{N}$ passing from the caecum is excreted as such.

As discussed by Dixon \& Nolan (1983), the microbial $N$ in caecal digesta determined by the ${ }^{15} \mathrm{~N}$ tracer method would have included microbial $\mathrm{N}$ of both rumen and caecal origin. During the $\left({ }^{15} \mathrm{NH}_{4}\right)_{2} \mathrm{SO}_{4}$ infusion into the rumen the enrichment of caecal microbial $\mathrm{N}$ was 0.44 of rumen bacterial $\mathrm{N}$ (Table 5). Furthermore, since some microbes would have been synthesized in the caecum from ${ }^{15} \mathrm{NH}_{3}-\mathrm{N}$ present in the caecal pool during infusion into the rumen $\mathrm{NH}_{3}-\mathrm{N}$ pool, the proportion of caecal microbial $\mathrm{N}$ consisting of rumen microbial 
$\mathrm{N}$ would actually have been less than 0.44 i.e. at least 0.56 of caecal microbial $\mathrm{N}$ was synthesized in the caecum. This indication of extensive caecal degradation of rumen microbial debris is in agreement with other estimates of digestion of other microbial constituents in the large intestine. In sheep given Trifolium subterraneum, Hogan (1973) reported 0.57 apparent digestion of the bacterial marker diaminopimelic acid between the ileum and the rectum and suggested a true digestibility of 0.65. Apparent digestion of bacterial cell-wall constituents of $0.20-0.40$ for diaminopimelic acid (Mason \& White, 1971), 0.68 for muramic acid (Mason \& Milne, 1971) and $0.75-1.00$ for $\alpha$-aminoisobutyrate (Harrison et al. 1971) has also been reported for sheep given forage diets. Judson et al. (1975) reported an apparent digestibility of 0.31 and a degradation of 0.42 of ${ }^{35}$-labelled rumen bacteria in the large intestine.

Only 0.17 of caecal microbial $\mathrm{N}$ was apparently derived from the caecal digesta $\mathrm{NH}_{3}-\mathrm{N}$ pool during $\left({ }^{15} \mathrm{NH}_{4}\right)_{2} \mathrm{SO}_{4}$ infusion into the caecum (Table 3). This value will underestimate the importance of caecal $\mathrm{NH}_{3}$ as a microbial substrate by the proportion of sampled caecal microbial $\mathrm{N}$ consisting of rumen microbial debris, but does suggest that $\mathrm{N}$ sources other than caecal $\mathrm{NH}_{3}$ were used extensively by caecal microbes. The small contribution of rumen microbial $\mathrm{N}$ to the caecal digesta $\mathrm{NH}_{3}$ pool, even though there was probably extensive degradation of rumen microbial debris, suggests that there may have been extensive re-incorporation into caecal microbes of the ${ }^{15} \mathrm{~N}$-labelled degradation products of rumen microbes. The low apparent digestibility of $\left[{ }^{15} \mathrm{~N}\right] \mathrm{NU}-\mathrm{NAN}$ of $0.25-0.27$ between the ileum and the rectum previously reported (Dixon \& Nolan, 1983; Dixon \& Milligan, 1984) can only be reconciled with extensive degradation of rumen microbial debris if there were extensive re-incorporation into caecal microbes of the ${ }^{15} \mathrm{~N}$-labelled degradation products. This hypothesis is consistent with the finding that in the rumen a considerable fraction of the bacterial $\mathrm{N}$ is apparently derived from peptides and amino acids, and this fraction increases as the concentration of peptides and amino acids increases (Nolan \& Leng, 1972; Maeng et al. 1976; Salter et al. 1979). Much higher concentrations of $\alpha$-amino- $\mathrm{N}$ in caecal liquid $(20 \mathrm{mg} \mathrm{N} / 1)$ than in rumen fluid $(7 \mathrm{mg} \mathrm{N} / 1)$ have been observed (Hecker, $1971 \mathrm{~b}$ ). Considering the extensive proteolysis and deamination in the caecum, amino acids and peptides may well be available as microbial substrates.

\section{CONCLUSIONS}

The present study was largely in agreement with previous experiments in this laboratory with sheep given lucerne hay. Estimates of blood urea transfer to the digesta in the caecum and the rumen were greater when determined with ${ }^{14} \mathrm{C}$ tracers than with ${ }^{15} \mathrm{~N}$ tracers. Appreciable hydrolysis of blood urea occurred in the caecal digesta pool, and much of this blood urea probably entered the caecum with ileal digesta. Considerable amounts of $\mathrm{NH}_{3}$ were also produced by proteolysis and deamination in the caecum. Although most of the $\mathrm{NH}_{3}-\mathrm{N}$ produced was absorbed from the large intestine it did not contribute substantially to microbial synthesis in the rumen, and the observation that most of the $\mathrm{NH}_{3}-\mathrm{N}$ was transferred to blood urea suggested that it was also not used for the synthesis of non-essential amino acids.

The financial assistance of the Australian Wool Corporation is gratefully acknowledged.

\section{REFEREN CES}

Allen, A. \& Miller, E. L. (1976). British Journal of Nutrition 36, 353-368.

Association of Official Analytical Chemists (1975). Official Methods of Analysis 12th ed. Washington, DC: AOAC. Beever, D. E., Thompson, D. J. \& Cammell, S. B. (1976). Journal of Agricultural Science, Cambridge 86, 443-452. 
Billich, C. O. \& Levitan, R. J. (1969). Journal of Clinical Investigation 48, 1336-1347.

Binnerts, W. T., Van't Klooster, A. T. \& Frens, A. M. (1968). Veterinary Record 82, 470.

Boda, K., Varady, J. \& Havassy, I. (1976). Tracer Studies on Non-Protein Nitrogen for Ruminants, vol. 3, pp. 1-12. Vienna: International Atomic Energy Agency.

Chalmers, M. I., Grant, I. \& White, F. (1976). In Protein Metabolism and Nutrition, pp. 159-179 [D. J. A. Cole, K. N. Boorman. P. J. Buttery, D. Lewis, R. J. Neale and H. Swan editors]. London: Butterworths.

Cheng, K.-J. \& Wallace, R. J. (1979). British Journal of Nutrition 42, 553-557.

Cocimano, M. R. \& Leng, R. A. (1967). British Journal of Nutrition 21, 353-371.

Coelho da Silva, J. F., Seeley, R. C., Beever, D. E., Prescott, J. H. D. \& Armstrong, D. G. (1972a). British Journal of Nutrition 28, 357-371.

Coelho da Silva, J. F., Seeley, R. C., Thomson, D. J., Beever, D. E. \& Armstrong, D. G. (1972b). British Journal of Nutrition 28, 43-61.

Dixon, R. M. \& Milligan, L. P. (1984). Canadian Journal of Animal Science 64, 103-111.

Dixon, R. M. \& Nolan, J. V. (1982). British Journal of Nutrition 47, 289-300.

Dixon, R. M. \& Nolan, J. V. (1983). British Journal of Nutrition 50, 757-768.

Dixon, R. M., Nolan, J. V. \& Milligan, L. P. (1982). British Journal of Nutrition 47, 301-309.

Engelhardt, W. v. \& Hinderer, S. (1976). Tracer Studies on Non-Protein Nitrogen for Ruminants, vol. 2, pp. 57-58. Vienna: International Atomic Energy Agency.

Hakim, A. A. \& Lipson, N. (1964). American Journal of Physiology 206, 1315-1320.

Harrison, D. G., Beever, D. E. \& Thompson, D. J. (1971). Proceedings of the Nutrition Society 30, 16A.

Hecker, J. F. (1969). Australian Veterinary Journal 45, 293-294.

Hecker, J. F. (1971a). British Journal of Nutrition 25, 85-89.

Hecker, J. F. (1971 b). British Journal of Nutrition 26, 135-145.

Hecker, J. F. (1973). Journal of Agricultural Science, Cambridge 80, 63-69.

Hogan, J. P. (1973). Australian Journal of Agricultural Research 24, 587-598.

Hoover, W. H. (1978). Journal of Animal Science 46, 1789-1799.

Houpt, T. R. (1970). In Physiology of Digestion and Metabolism in the Ruminant, pp. 119-131 [A. T. Phillipson, editor]. Newcastle upon Tyne: Oriel Press.

Judson, G. J., Abdelsamie, R. \& Bird, R. P. (1975). Australian Journal of Agricultural Research 26, 743-749.

Kennedy, P. M. (1980). British Journal of Nutrition 43, 125-140.

Kennedy, P. M. \& Milligan, L. P. (1977). Proceedings of the Nutrition Society 36, 53 A.

Kennedy, P. M. \& Milligan, L. P. (1980). Canadian Journal of Animal Science 60, 205-221.

Kornberg, H. L. \& Davies, R. E. (1955). Physiological Reviews 35, 169-177.

Kornberg, H. L., Davies, R. E. \& Wood, D. R. (1954). Biochemical Journal 56, 355-363.

Leng, R. A. \& Leonard, G. J. (1965). British Journal of Nutrition 19, 469484.

MacRae, J. C., Reid, C. S. W., Dellow, D. W. \& Wyburn, R. S. (1973). Research in Veterinary Science 14, 78-85.

MacRae, J. C. \& Ulyatt, M. J. (1974). Journal of Agricultural Science, Cambridge 82, 309-319.

Maeng, W. J., Van Nevel, C. J., Baldwin, R. L. \& Morris, J. G. (1976). Journal of Dairy Science 59, 68-78.

Mann, J. \& Gurpide, E. (1966). Journal of Clinical Endocrinology and Metabolism 26, 1346-1354.

Mason, V. C. \& Milne, G. (1971). Journal of Agricultural Science, Cambridge 77, 99-101.

Mason, V. C. \& White, F. (1971). Journal of Agricultural Science, Cambridge 77, 91-98.

Mossberg, S. M. \& Ross, G. (1967). Journal of Clinical Investigation 46, 490-498.

Nolan, J. V. \& Leng, R. A. (1970). British Journal of Nutrition 24, 905-915.

Nolan, J. V. \& Leng, R. A. (1972). British Journal of Nutrition 27, 177-194.

Nolan, J. V. \& Leng, R. A. (1974). Proceedings of the Nutrition Society 33, 1-8.

Nolan, J. V., Norton, B. W. \& Leng, R. A. (1976). British Journal of Nutrition 35, 137-147.

Nolan, J. V. \& Rowe, J. B. (1976). In Reviews in Rural Science, vol. 2 pp. 151-159 [T. M. Sutherland, J. R. McWilliam and R. A. Leng, editors]. Armidale, Australia: University of New England Publishing Unit. Nolan, J. V. \& Stachiw, S. (1979). British Journal of Nutrition 42, 63-80.

Norton, B. W., Jones, A. N. \& Armstrong, D. G. (1982). British Journal of Nutrition 48, $265-274$.

Norton, B. W., Murray, R. M., Entwistle, K. W., Nolan, J. V., Ball, F. M. \& Leng, R. A. (1978). Australian Journal of Agricultural Research 29 595-603.

Salter, D. N., Daneshvar, K. \& Smith, R. H. (1979). British Journal of Nutrition 41, 197-209.

Shipley, R. A. \& Clark, R. E. (1972). Tracer Methods for In Vivo Kinetics. New York and London: Academic Press.

Snedecor, G. W. \& Cochran, W. G. (1967). Statistical Methods, 6th ed. Ames, Iowa, USA: Iowa State University Press.

Ulyatt, M. J., Dellow, D. W., Reid, C. S. W. \& Bauchop, T. (1975). In Digestion and Metabolism in the Ruminant, pp. 119-133 [I. W. McDonald and A. C. I. Warner, editors]. Armidale, Australia: University of New England Publishing Unit.

Wolpert, E., Phillips, S. F. \& Summerskill, W. H. J. (1971). Lancet ii 1387-1390. 